Florida International University FIU Digital Commons

$11-7-2008$

\title{
Inventing indigenous religious belief and practice within the spaces of Ghanaian Pentecostalism : the Mame Wata healing churches of Half Assini
}

Genevieve Nrenzah

Florida International University

DOI: $10.25148 /$ etd.FI14091600

Follow this and additional works at: https://digitalcommons.fiu.edu/etd

\section{Recommended Citation}

Nrenzah, Genevieve, "Inventing indigenous religious belief and practice within the spaces of Ghanaian Pentecostalism : the Mame Wata healing churches of Half Assini" (2008). FIU Electronic Theses and Dissertations. 1564.

https://digitalcommons.fiu.edu/etd/1564 
FLORIDA INTERNATIONAL UNIVERSITY

Miami, Florida

INVENTING INDIGENOUS RELIGIOUS BELIEF AND PRACTICE WITHIN THE SPACES OF GHANAIAN PENTECOSTALISM: THE MAME WATA HEALING CHURCHES OF HALF ASSINI

A thesis submitted in partial fulfillment of the requirements for the degree of MASTER OF ARTS in

RELIGIOUS STUDIES

Genevieve Nrenzah

2008 
To: Dean Kenneth Furton

College of Arts and Sciences

This thesis, written by Genevieve Nrenzah, and entitled Inventing Indigenous Religious Belief and Practice within the Spaces of Ghanaian Pentecostalism: The Mame Wata Healing Churches of Half Assini, having been approved in respect to style and intellectual content, is referred to you for judgment.

We have read this thesis and recommend that it be approved.
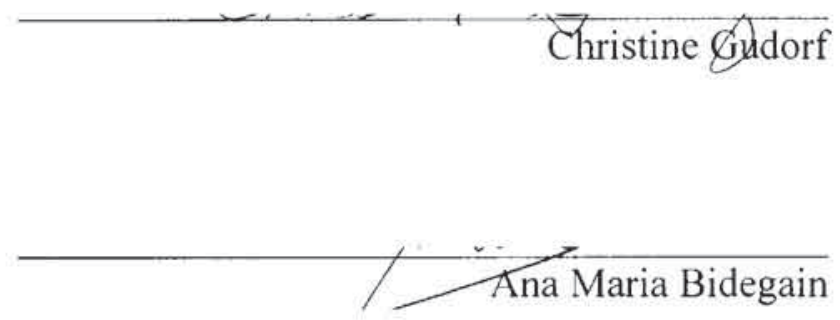

Albert K. Wuaku, Major Professor

Date of Defense: November 7, 2008

The thesis of Genevieve Nrenzah is approved.

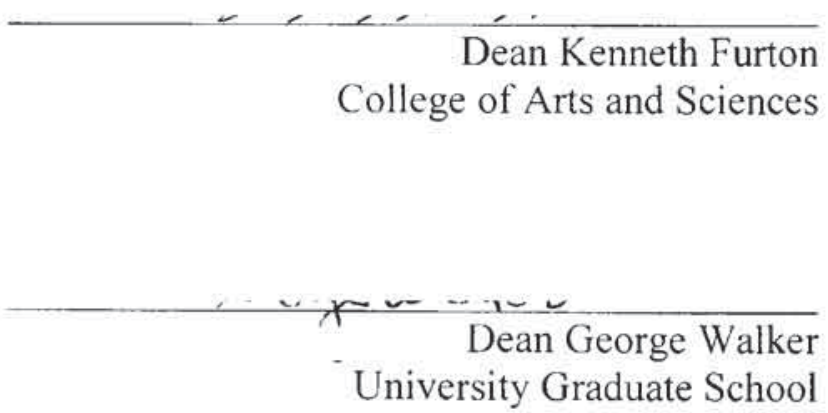

Florida International University, 2008 
(C) Copyright 2008 by Genevieve Nrenzah

All rights reserved. 


\section{DEDIC $\triangle T I O N$}

I dedicate this thesis to my father A. A. K. Nrenzah, my uncle Randolph Acquah. my mother Elizabeth Acquah. my grandmother Nana Benee Ackah and all my siblings, especially my big brother Rev. Fr. Mark Anthony Nrenzah. I owe my success to all of them. They taught me that success comes with determination and hard work. 


\section{ABSTRACT OF THE THESIS \\ INVENTING INDIGENOUS RELIGIOUS BELIEF AND PRACTICE WITHIN TIIE SPACES OF GHANAIAN PENTECOSTALISM: THE MAME WATA HEALING CHURCHES OF HALF ASSINI}

by

Genevieve Nrenzah

Florida International University, 2008

Miami. Florida

Albert K. Wuaku, Major Professor

Goddesses in African religions are spirits that affect humans and demand reverence from them. They are also embodiments of ideas that $\Lambda$ frican people have about women, their powers and their roles in society. This study focused on Mame Wata, a goddess in Half Assini, an Nzema-speaking coastal community in western Ghana. It sought to resolve a paradox, that is, the fact that, the goddess is at the center of a Pentecostalist tradition even though traditional Pentecostalism in Ghana views her as an agent of the devil.

The study involved fieldwork in this community of the goddess's female worshippers led by $\Lambda$ gyimah, a charismatic man, and an agent of the goddess. The study interpreted the goddess as a post-colonial invented symbol personifying both pre-colonial and emerging ideas about female power. Findings from the study also show that through Mame Wata the followers celebrate the spirituality of the female. 
CHAPTER

INTRODUCTION 1

1. CONCEPTUALIZING THE ISSUES

The Themes 5

$\begin{array}{ll}\text { Charisma } & 7\end{array}$

Invented Tradition 11

2. MAME WATA, THE WATER GODDESS 15

$\begin{array}{ll}\text { The Goddess`s Characteristics } & 15\end{array}$

$\begin{array}{ll}\text { Mame Wata in Traditional Pentecostal Discourse } & 19\end{array}$

3. THE FIELDWORK 23

The Geographical Setting: The Village and the People of Half Assini 23

The Religious Life of Hall Assini 25

Political Life $\quad 26$

Social Life 26

$\begin{array}{lr}\text { Participant Observation } & 27\end{array}$

Interviews 28

The Experience of the Field: Going home 29

Renegotiating My Entry 31

Some Challenges $\quad 32$

4. THE NZEMA TRADITIONAL RELIGION: THE PIACE OF WOMEN 33

The Nzema

Women in Nzema Religion 36

Nzema Women $\quad 36$

Women and Spirituality in Nzema Traditional Religion 37

$\begin{array}{ll}\text { God as Female } & 38\end{array}$

The Female as Earth 38

$\begin{array}{ll}\text { The Female Body } & 39\end{array}$

Women. Power and Water 41

Colonialism and the Decline in Nzema Women's Power 43

Post-Colonial Nzema $\quad 46$

Globalization and the Present Situation $\quad 46$

5. MEMOIRS OF CHRIST DELIVERANCE CHURCH'S ORIGINS:

CHARISMA AND THE INVENTION OF A RELIGIOUS COMMUNITY 52

The Founder and the Founding of the Community: The stories 53 
6. THE "CHILDREN OF MAME WATA": THE WORSIIIPPING

COMMUNITY

The Followers: Mame Wata's Children

Tenets

63

Ritual Life

65

The "Fete" Event

7. THE FEAR OF MAME WATA- REVISTING THE MYSIERY OF THE FEMALE

The Fear of Mame Wata

8. EMPOWERING WOMEN

Mame Wata: Mother and Healer

"If you want a child she will give you a child" 82

Success in Business

CONCLUSION 


\section{INTRODUCTION}

An earlier encounter with beliefs about the healing abilities of Nzema women made me curious and this curiosity has nurtured and sustained my academic interest in the power of females and the various ways in which Ghanaians expressed the belief in this power till this day. The encounter raised questions for which I am presently seeking answers. This event happened at Half Assini, my home town. I was twenty years old and as a favorite of my grandmother, Nana Bene, when I would go to the village during school vacations I would accompany her to her stall in the market to sell her items on Tuesdays and Saturdays, which were the main market days. It was during one of such trips to the market that I was introduced to a local discourse and practice relating to women and their healing powers through an experience.

I had stepped on an object and suddenly a burning sensation run through my left foot. "It is evil medicine," my grandmother said. "It may have been placed there for someone else and you stepped on it accidentally. Let's get help," she said. We quickened our pace and dashed into the market. "Which of you is in her menses, please come and urinate on Mame Homa's foot for me, she just stepped on bad medicine," my grandmother screamed. I looked on puzzled, not knowing what to do or think. Suddenly an elderly woman emerged from behind her wares in a stall, tied a cloth around her waist and urinated on my foot. Encouraged by this act other women took turns to urinate on my foot. Suddenly the burning sensation went away and I felt no pain in my foot any longer. 
I would learn later from my grandmother and other sources that the vagina was a spiritually charged part of the female anatomy and that through its usage the female is able to participate with God in the creation of another human. I would also learn that the vagina has spiritual potency greater then the powers of most male spiritual specialist, and that menstrual blood was spiritually powerful and could neutralize other supernatural sources of power. I wondered whether my grandmother's explanation had any thing to do with the fact that many healers I knew in Half Assini were women. More importantly, I wondered about the power of the female in traditional African societies if it was believed they had such spiritual powers.

My interest in African traditional medicine was kindled by this experience and this would eventually lead to my interest in the Christ Deliverance Church, a religious community in Half Assini with a predominantly female following. At the center of the tradition of this community is Mame Wata a goddess, whose ability to heal is celebrated in Half Assini. Initially I was interested in how she healed her followers. But as I began to learn more about the community I noticed there was more to the phenomenon than Mame Wata's healing. It was also a Pentecostal tradition. This realization really got me puzzled, for traditional Pentecostalism has no place for African gods and goddesses. They are viewed as agents of the devil. I wondered how an African goddess could be the focal point of worship in a Pentecostal church.

While studying at studying at Florida International University, I decided to pursue this research interest further. I traveled to Ghana in the summer of 2008 to do field research in the religious community and this work is the product of my research. 
I found out that the founder of the community was inspired by the goddess to create the community. I noticed also from the attributes of the goddess that she embodied notions the Nzema had always held about the power of women in society. She was a modern invention embodying traditional notions about women. But she also embodied ideas about women in Ghana that are trickling in from the west as part of the world wide circulation of ideas globalization is encouraging. I found out also that she appealed to the women because they believed she healed them, helped them in their business ventures, provided children for them and was an example of what a woman ought to be for them. In other words she empowered them and helped them to cope with their daily challenges.

I concluded that the founder sought to re-introduce ideas about Nzema women in Half Assini and adopted Christianity as the framework within which he would be able to do this. He also adopted a goddess that embodied these ideas and this made the group appealing to women. Thus, within a space furnished by Christianity, women are celebrating and drawing strength from traditional ideas and emerging notions about them. These are the themes that I develop in this study. I have organized them along the following lines:

Two main themes, charisma, and the invention of traditions, emerged consistently in the course of my interviewing and observations in the community. In chapter one I review the conceptual frames that underlie these themes. Putting these ideas together I build a framework that will help us make intellectual sense of the religious lives of the community. In chapter two I review the literature on Mame Wata the water goddess, pointing out some gaps in it that the study will hopefully fill. Chapter three describes my research in the field, the setting and my experiences while collecting the information that 
went into the writing of the study. In chapter four I write about the different ways in which the spirituality of the female was celebrated in pre-colonial traditional Akan, especially Nzema societies. I describe how these ideas declined because of the impact of colonization and expansion of Christianity. I proceed to discuss the contemporary situation that is inspiring the invention of these ideas in the form of Mame Wata and her adoption in this Half Assini Pentecostal church. Chapter five describes the origins of the community, drawing on the memoirs of the followers in the community of the events. In chapter six I describe the worshipping community and its basic tenets.

One of the main themes that emerged in the course of my field research was the fear, mystery, awe, respect or reverence surrounding the persona of Mame Wata. Most of the narratives told of the very frightening scenes or episodes that heralded her appearances to those who encountered her. Chapter seven reports some of these stories. I argue that they are reminiscent of the power, awe, and mystery of the female in traditional Nzema thinking.

Christ Deliverance church is a church that empowers female members. In chapter eight I describe how Mame Wata's role is crucial in this empowerment. In the conclusion chapter I tie together the strands of the arguments that run through the study. 


\section{CHAPTER ONE \\ CONCEPTUALIZING THE ISSUES}

When I began this investigation into the worship of Mame Wata in Ghanaian Pentecostalism, I only had a vague sense of the possible theoretical concepts I could use to capture the religious lives of the Christ Deliverance Church community. In the proposal I presented to my thesis committee before proceeding to do field studies I indicated a number of concepts that might be helpful. But my aim was neither to test nor to confirm these theoretical concepts. My plan was to rather proceed to the field with broad and general questions about Mame Wata and the religious lives of her followers, and I hoped that during the course of the study their responses would generate ideas I could use for conceptual analysis. Thus, I entered the field with an open mind as far as theory is concerned. As I interviewed the lay members and leaders of the Christ Deliverance Church and observed them in the course of my participation with them in their activities during worship and at other social gatherings, a number of themes began to emerge. In this chapter I will indicate what the main themes are, and review the conceptual frames that seem to underlie them. Putting these ideas together I will build a framework that will help us make intellectual sense of the religious lives of the community

\section{The Themes}

Two main themes emerged consistently in the course of my interviewing and observations in the community. One of these themes is the idea that followers of Mame Wata believe that the founder of their religious community had special connections with 
the Goddess. The stories told to me about how he founded the group all pointed to the fact that his followers believed he was an agent of Mame Wata and was on a mission to accomplish goals set for him by the goddess. For them the founding of the community was one of those goals. Mame Wata then was the real head of the community and the founder responded to her directives.

Another theme that emerged was that the followers, and also the townsfolk of Half Assini, lived in fear and awe of the power of Mame Wata. This theme emerged clearly from the stories I was told about the frightening encounters some members of the religious community and the villagers had had with the goddess, the reluctance of some followers to even mention the goddess lest she haunt them for talking about her without her permission, testimonies about the goddess's ability to heal or to bestow or withhold abundance, and her ability to make those who defied her rules go mad, to mention only some of the highlights of the narratives floating around about the goddess. These accounts reflected a strong belief in the power of the goddess. I came away with the idea that through the regular performance of rituals, and the discourse floating around about the goddess, the community provided an avenue for the celebration of the pre-colonial indigenous ideas about the power of and mystery surrounding the female. The goddess embodied these ideas, so in essence, through her; followers were reliving or revamping the sense of fear, respect and awe that was associated with Nzema women in pre-colonial times.

In developing these two main themes, we will focus attention on two concepts. The concepts are charisma and the invention of traditions. First I will analyze these concepts individually. But I will also examine them in terms of how they can be built 
upon and put together to provide the framework for understanding the community's origins and the religious experiences of the followers.

\section{Charisma}

We turn our attention to the first major concept, that of charisma. The study will interpret the origins of the religious community as a product of the charisma of the leader. In doing this I will develop the concept of charisma and seek to explain how the charisma of the founder is based on the belief that he is an agent of Mame Wata, the goddess, and the symbolic representation of ideas about female power. In other words, the founder's authority and the authority of priests as leaders in this community is dependent on their connections with a goddess --a female-- in a modern society that tends to be influenced strongly by patriarchal notions introduced through colonialism.

The religious sense of the word charisma refers to the demonstration of supernatural endowment by religious leaders. According to Weber, who popularized this concept, the charismatic leader has a divine gift and demonstrates this to his followers by miracles, signs and proofs.' Weber also says that the obedience of the followers is contingent upon the belief or faith that the leader has powers. In fact a leader who fails to demonstrate the divine connection may lose his or her following. This means that a charismatic person or leader must constantly show that he or she is still in control of those powers. Charismatic leaders may do so in a number of ways. For example, in southern Ghana the followers of a charismatic leader would expect him or her to fulfill

\footnotetext{
${ }^{1}$ Reinhard Bendix, Max Weber: An Intellectual Portrait ( New York: Doubleday and Company Inc.1962), 299.
} 
their physical and spiritual needs. He or she would have to solve their problems in miraculous ways: heal their incurable illnesses, intervene in their favor in difficult and intricate cases and protect them from fatal accidents or against evil powers of enemies and witches. It is said of such a person that he or she has the capacity to "work" or is "working" [Nzema-Oye ejuma].

In the local religious terms "work" or "ejuma"2 is the manifestation of spectacular spiritual power as is seen through a person's ability to go beyond the normal course of events, to possess knowledge beyond ordinary human ability, to perform miracles, ward off evil powers and to help followers realize life's objectives. The traditional religious grounds for the belief in a leader's charismatic powers among the Nzema in Ghana is the notion that the world or "ewiase" is filled with mystical power from Edenkema or God and that persons can use this power source for benevolent or malicious purposes. The "worker" is normally one who has acquired the secrets required to tap into Edenkema's power either through training, intuition, or because a god or goddess may have chosen him or her as the one through whom he or she would transmit these divine powers. Such a person then becomes agent of the goddess or god and uses the powers to perform "works" that benefit individuals in society.

One factor that contributes to the charisma of a religious leader is social crisis. ${ }^{3} \mathrm{~A}$ crisis of some sort will regularly prevail in all societies and, as Goody has pointed out, it is not always easy to point to, or measure the level of chaos or crisis in any given time

\footnotetext{
${ }^{2}$ Ejuma as referred to here means the charismatic leader is very powerful, potent and does well in his work. 3'Bendix, 299.
} 
in any society. ${ }^{4}$ But crisis gives birth to a state in which people are expecting some one to emerge with the "answer" to the situation. Followers of charismatic leaders often seize such opportunities to claim that their leaders are agents of a divine being sent with the answers they need to solve a given crisis situation. Furthermore, charismatic persons often derive their popularity from challenging established religious practices, saying or doing or introducing the "unthinkable." ${ }^{5}$ Charisma, then, is very revolutionary in nature. The values that the leaders introduce and their practices are often new and deviate from what society would consider very normal.

In the chapters that follow I will demonstrate that Osofo Agyimah, the founder of the Christ Deliverance Church, is a charismatic figure. I will report stories told to me about the mysterious circumstances of his birth and early childhood, which point to the belief that he was chosen by Mame Wata to become her agent and is therefore equipped with supernatural powers from her. I will also demonstrate how he founded a religious community, drawing largely on the belief among the people of Half Assini that he was Mame Wata's agent and therefore had the power to heal and perform other "works". The study will show that the community's origin then represents the highest point in the career of Agyimah as a charismatic person. I will also describe the difficult socioeconomic situation in Ghana at the time of the rise of Agyimah as a religious leader, which created conditions congenial for his emergence as a charismatic figure. The

\footnotetext{
${ }^{4}$ Jack Goody. "Anomie in Ashanti," Africa, 27 (1957), 356-63.

${ }^{5}$ Bendix, 300.
} 
situation helped in creating what $\mathrm{O}^{\prime}$ Brien has described as "a charismatic clientele" ${ }^{16}$ - a people ready to believe in miracles. During this time in Ghana many God-men and Godwomen --charismatic persons-- arose and, because of their charisma, developed their leadership potential to the extent that they won the recognition and acceptance of groups of people who, under normal circumstances, would not have followed them or their traditions. For this reason the era witnessed a spectacular florescence of new religions. ${ }^{7}$ It was no coincidence that Agyimah rose to public prominence around the same period and was able to establish the worship of an African goddess within a Pentecostal tradition.

In the study I will also show how Agyimah derives his attraction from challenging established religious practices within Pentecostalism. I will argue that his adoption of this goddess as the center of his Pentecostal tradition was unheard of. It was revolutionary. Before this time, not many Pentecostal groups embraced the worship of African deities, especially, Mame Wata, who in traditional Ghanaian Pentecostalist circles is described as an agent of the devil. There is no doubt that Agyimah's bold move made the people in Half Assini believe all the more that he was chosen by a powerful goddess, Mame Wata.

\footnotetext{
${ }^{\circ}$ Cruise O'Brien Donal B. "Charisma Comes to Town: Mouride urbanization 1945-1986",in Donal B. Cruise O'Brien and Christian Coulon (eds.). Charisma and Brotherhood in African Islam, 1988, Oxford. Clarendon Press, pp. 135-155.

7 Max Assimeng. Religion and Social Change in West Africa. Accra (Ghana University Press, 1989), 15.
} 


\section{Invented Tradition}

The concept of "invented tradition" has been the focus of post-modern studies in history and anthropology. ${ }^{8}$ In my study, I will use the concept as it has been defined and developed by Hobsbawm, who says an invented tradition is:

A set of practices, normally governed by overtly or tacitly accepted rules and of a ritual or symbolic nature, which seek to inculcate certain values and norms of behaviour by repetition, which automatically implies continuity with the past."

To restate Hobsbawm's definition, "invented tradition" refers to a set of societal practices, beliefs, institutions and norms that have been deliberately or accidentally re-established by a community. These traditions help people to forge links with their past.

Hobsbawn cautions us against confusing "invented traditions" with "customs." He says whereas "customs" [regular practices of daily life or cultural events] are seen as changing constantly, "invented traditions" are, in the eyes of the inventors, unchangeable. This means that, even though we as scholars will describe a tradition as invented, for the inventors themselves the tradition has the same old symbolic value, function, force or meaning as past practice or practices. ${ }^{10}$

Inventors of traditions often intend to revamp norms or organizations supposedly rooted in the past in order to deal with new social circumstances. A motivation behind the inventions is then to give the impression that the things have

\footnotetext{
${ }^{8}$ David Cannadine, "The Context, Performance and Meaning of Ritual: The British Monarchy and the Invention of Tradition 1820-1977." The Invention of Tradition, eds. Hobsbawm, E. and Ranger, T. (Great Britain: Cambridge University Press, 1983), 101.

${ }^{9}$ Hobsbawm, 1.

${ }^{10}$ Ranger, 254-255.
} 
remained just as they were in the past. As Cannadine writes of the maintenance of the "pageantry" of the British monarchy as an application of the concept, "the ceremonial is now splendidly performed so much so that observers have assumed that this was always the case." We must note that Cannadine uses the verb "assume." This underscores the fact that the "inventions" are simply "make believes." All the same, they generate in the participants a deep sense of comfort due to their attachment to their past traditions or heritage. Hobsbawm himself notes that the continuity that the traditions seek to establish is simply 'make believe' or "fictitious." 12

Hobsbawn identifies some factors that make communities invent traditions. First, he says radical or drastic changes in society may destabilize the existing norms and practices, causing new conditions to emerge for which the old traditions might not be suitable. ${ }^{13}$ As the existence of communities depend on their indigenous institutions and norms appearing to be relevant, it then becomes necessary for the leaders to come up with new traditions. He also says that when an old tradition becomes irrelevant or when its custodians have died off, it becomes necessary to invent a new tradition. ${ }^{14}$ We can see from these situations that the invention of tradition occurs as a response to changes in society.

\footnotetext{
${ }^{11}$ Cannadine. 102.

${ }^{12}$ Hobsbawn, 2.

${ }^{13}$ Hobsbawm, 4-5; Ranger, 211-263.

${ }^{14}$ Hobsbawm, 4-5.
} 
Hobsbawm describes "three functions of invented traditions." ${ }^{15}$ He says some traditions are invented to serve as symbols of a group's identity. As an illustration Trevor-Roper demonstrates the invention of a "highland tradition"16 by the Scottish as an identity symbol and a sign of resistance against the British. Invented traditions also function to set up new traditional offices or practices, and/ or reinforce already existing ones by placing an authoritative cultural stamp on them. Thirdly, traditions are invented with a view to aiding in the transfer of certain practices and values to subsequent generations. ${ }^{17}$ In this study we shall see that these three functions of "invented" traditions are connected and often overlap.

Most of the scholars who have used invented tradition as a concept use it to demonstrate not only how traditions are invented but also how the invented traditions unite people for political action. ${ }^{18}$ The concept, however, seems useful in a broader sense as well, and can help to explain how people adapt to new life situations. In this study I will adopt the concept to help explain how the women of Half Assini are re-establishing old religious beliefs and practices concerning women to find answers to new problems introduced by changes in their lives. The process of inventing traditions in the Christ Deliverance healing church can be seen in two ways in this study. First, the study will show that Mame Wata, the goddess who inspired Agyimah to found a religious community, is an invented symbol that personifies ideas about the power of females.

\footnotetext{
15 Hobsbawm, 9.

${ }^{16}$ Trevor-Roper, 15-41.

${ }^{17}$ Hobsbawn, 9.

${ }^{18}$ Cannadine, 101; Clifford, 277; Hobsbawm, 15; Ranger, 309.
} 
Second the study will also demonstrate the re-introduction of African religious beliefs and practices into a community that is supposed to be Christian. The study will go on to demonstrate the needs that these inventions meet for the women in a modern Nzema society. The study also builds on this concept in arguing that when traditions are invented by local people in a rapidly globalizing context, alien ideas floating about as part of a global circulation are incorporated into the invented traditions. These ideas are however transformed, in that they are invested with meanings that are indigenous to the inventors. This is the only way these ideas can be pressed into service to cater to local needs.

In conclusion, the study puts together two concepts, charisma, and invention of traditions, to demonstrate how a charismatic man, Agyimah, uses his powerful influence to reintroduce traditional religious beliefs and practices into a Pentecostal tradition. In doing this, he was inspired by a goddess who symbolizes the power of women, which they lost because of the influence of colonialism. Through this goddess, Agyimah's followers, who are predominantly female, are celebrating these old ideas about female power and using them to help themselves in an Nzema society in which globalization has introduced so many new challenges. 


\section{CHAPTER TWO}

\section{MAME WATA, THE WATER GODDESS}

In this chapter, I will introduce my readers to Mame Wata by discussing the literature on her. In doing this I will identify some themes relevant to the present study and point out some gaps that the study will fill.

Mame Wata is a goddess worshipped in most communities in Africa. In Ghana, mostly people who live along the coast and rivers worship her. In the very extensive literature on this goddess, she is referred to as "Mame Wata", or "mammy water." In this study, I will refer to her as "Mame Wata" because this is how the local people of Half Assini refer to this water goddess.

\section{The Goddess's Characteristics}

We learn a lot about the traits associated with this goddess from many authors who have written about her. She is described as half woman, half fish and a mermaid who possesses extraordinary beauty. Bastian describes her as an "elegant woman, very beautiful, combing her long black hair with a golden comb." ${ }^{19}$ It is said that women who are extremely beautiful are connected with her. Her sketches in pictures depict affluence and good health.

One theme that the literature on the goddess stresses is her power. In places where people worship her in Ghana ${ }^{20}$, it is said that the powers of most local gods cannot match hers. For instance in some parts of the Volta region of southern Ghana the ways in which

\footnotetext{
${ }^{19}$ Bastian, 2.

${ }^{20}$ Albert Wuaku, Tapping into Hindu Powers: Krishna and Shiva Worship in Ghana. Phd Thesis, Toronto University, 2004, 200.
} 
her followers describe her show that they believe her powers are superior. She is described as a beautiful woman who appears carrying a basket or a sieve full of water [an impossible task by human beings] and wearing a very severe look on her face. She is also seen as a powerful goddess with a strong will. She would possess or "descend on" a follower and forcefully use him or her as a mouthpiece. In a small community on the banks of the Volta River in southern Ghana called Abidjan Mame Wata Village, shouts of "egbona! egbona!"'She is coming! She is coming!] can be heard when a Mame Wata possession takes place and onlookers would scamper around seeking refuge from the person who is possessed by the much-feared Mame Wata. Sometimes Mame Wata appears in dreams and would continually harass a person she has chosen to be her follower until the one gives in to her will. ${ }^{21}$ She would seize a man and forcefully make him her lover and would insist that the man must avoid sexual contact with other women. In addition, she does not allow some of her female devotees to marry men, because they are spiritually married to her.

Another theme in the literature on the goddess is her benevolence. A wealthy trader, Mame Wata supplies her followers with modern goods, grants them power and ensures their success in their endeavors. Though she is barren, the goddess gives children to her followers who are in need of them. ${ }^{22}$ In some coastal villages of southern Ghana where she is worshipped, it is said that Mame Wata would appear in the day at market places as a tall, slim, and very beautiful European woman to supervise the market

\footnotetext{
${ }^{21}$ Drewal, 161.

22 Bastian, 2.
} 
activities. She would reward her devotees with wealth, especially money. ${ }^{23}$ It is said that the prize to pay for her benefits could, however, be high. Mame Wata can deny a woman a happy relation with her husband or children in return for the wealth she/he gets from her.

Bastian describes how Mame Wata selects her followers. She would make the person sick with an incurable disease first before healing him or her. After she heals the person, he or she becomes her servant. This makes her detractors view Mame Wata as having a dual nature, that is, she can be good and bad. Bastian notes that she is both an "afflicter and healer, destructive and creative, red and white." 24 As both afflicter and healer she reflects an African belief that the "power which afflicts suffering is also the one that must be approached for a cure. ${ }^{25}$ This makes us interpret the goddess as an embodiment of African ideas as well as a spirit.

Scholars have also described the mode of communication with the goddess differently. Drewal says that devotees use mirrors as a mode of contact with the goddess. ${ }^{26}$ My own experience of the deity in Half Assini supports this view. People here describe Mame Wata as a beautiful woman who likes looking at herself all the time in the mirror. Devotees therefore use the mirror to attract her to come to them. Some people however, use other means to communicate with the deity. They hold a bowl of seawater in their hands and after incantations, the priest calls Mame Wata and mentions the

\footnotetext{
${ }^{23}$ Drewal, 161.

${ }^{24}$ Bastian, 3.

${ }^{25}$ Frank. 341 .

${ }^{26}$ Drewal, 3.
} 
reasons for calling. At other times, the priest goes to the seashore in the middle of the night to invite her and ask for directions, healing powers or some other favor. Dreams and visions are other means of contacting Mame Wata.

Scholars speculate that Mame Wata is a foreign goddess transported to AfricaGhana. ${ }^{27}$ The basis of their speculations is the way worshippers describe the goddess and the images of her. Bastian identifies a number of elements about the goddess that point to her foreignness. One is her fair skin as demonstrated in her depictions. She suggests however, that, the fairness of skin tone attributed to her may also come from indigenous color categories. ${ }^{28}$ She mentions other traits. These include her pointed nose, her long eyelashes, and her unusually long and flowing hair, all of which she says, suggest that her worshippers believe she comes from Europe or Asia. ${ }^{29}$

For Drewal, it is the chromolith image of a snake charmer seen in Mame Wata depictions that suggests her foreign origins. ${ }^{30}$ Drewal suggests, first, that this image is non-African. considering the skin color of the snake Charmer and her long flowing hair ${ }^{31}$. Another reason he provides is that the paintings of the goddess are neither black nor white. He suggests that most likely, this origin is India. In explaining how this portrait found its way into Africa, Drewal says it must have been circulated by Indian traders and migrants who traveled to and settled in different parts of the continent. African people

\footnotetext{
${ }^{27}$ Meye,r 1999, 2003; Wicker, 2000:199-222; Drewal, 1988, and Hackett, 200.

28 Misty L. Bastian, "Married in the Water: Spirit Kin and Other Afflictions of Modernity in Southeastern Nigeria, " Journal of Religion in Africa, Vol 27, fasc.2 (May 1997), 2.

${ }^{29}$ Bastian, 1 .

${ }^{30}$ Drewal. 2.

"Drewal, 98.
} 
later adopted it as the photograph of Mame Wata. I do not share Drewal's claims about Mame Wata's foreignness. I suggest that she is a local African goddess who has different images. some foreign. others local. African worshippers adopt and adapt foreign symbols in their worship traditions, not only because African religions are open to other forms of worship but also because alien spiritual symbols are believed to contain unfamiliar and untested spiritual power. People or groups that adopt such symbols feel they have an advantage over others because they possess an uncommon spiritual power source. Furthermore, the images and paintings associated with the goddess could be foreign. but the meanings invested in these images are traditional and very African. This is what happens when local people invent practices. They incorporate into the new practice any element available that might be useful to them. Drewal himself hints at this fact when describes the Mame Wata experience as an "invention of culture." Wicker shares Drewal's viewpoint and goes on to identify the different cultural strands in the worship tradition of the goddess. namely the African cultural strand, the European strand, the new world strand. and the Indian strand. ${ }^{.32}$

\section{Mame Wata in Traditional Pentecostal Discourse}

Meyer has written extensively about how worshippers in Ghana’s Pentecostal Churches view Mame Wata. She says that Pentecostalism does not deny the existence of other spiritual forces but then they see them as "false gods" and Mame Wata is one of those false spirits. Meyer describes how Pentecostal churches have cast a slur on the

\footnotetext{
Hicker. 2000. 199-203.
} 
image of Mame Wata, referring to her as the servant of the devil, and a Christian demon, that is, a demon whose specialty is attacking Christians.

Meyer also describes how Pentecostals have categorized Mame Wata as a marine spirit and associated her with polygamy, fornication, anger, homosexuality, lesbianism, adultery, idolatry, poverty, backwardness, and all that is evil. In the Pentecostalist discourse in Ghana, marine spirits are dangerous, wicked and very cunning. Pentecostalcharismatic Christians guard their members against them. According to Meyer, even Mame Wata's "images or paintings are perceived by Pentecostals as having the power to bring one under a spell. ${ }^{33}$ The prayers of the Pentecostal churches are directed at putting her in her proper place -the bottom of the sea.

Quite absent from the literature on the goddess are discussions about the significance of her sex to her worshippers, who for the most part are females. This aspect of the tradition needs to be highlighted, because in African traditions goddesses are more than spirits to their worshippers. They embody ideas about females in the societies that worship them. From my personal observation of the worship of this goddess in Half Assini, I would suggest that the Mame Wata tradition represents a modern re-invention of ancient African beliefs regarding the female and her spirituality. It is not clear when this re-invention began to take shape in African communities. What we know, however, is that the rise in the worship of Mame Wata coincided with the rise in women-led spiritual churches in Africa in the early to mid 1900s ${ }^{34}$ This gives us cause to believe that this invention was a response to the quest for spiritually powerful female symbols to reinforce

\footnotetext{
${ }^{33}$ Meyer, 2000, 7 .

${ }^{34}$ Omenyo, 61 .
} 
the women-led spiritual church movement. The fact that Mame Wata has foreign characteristics as scholars have identified, is only a reflection of the modern context in which this invention has been taking shape, for, in the invention of traditions, local people make use of the alien symbols that are flowing into their spaces as part of a global circulation. Followers therefore appropriate alien symbols of spiritual power and invest them with local meanings, so that they can press them into service as they deal with their problems. In this study, I will focus on a very modern extension of this phenomenon in Half Assini, that is, the adoption of the goddess by female worshippers who draw on her for strength and inspiration as they negotiate their lives through the difficulties that globalization has imposed on them.

The literature on the goddess also assumes that Pentecostalism and the Mame Wata worship tradition are antithetical. However, this is not the situation in the Half Assini community. The followers say their church is a Pentecostal church. Yet, they describe the tradition as indigenously Nzema. They agree that the central focus of the tradition is Mame Wata. They explain that Mame Wata is God's daughter and has God's powers. Angels, for them, are Nzema spirits that help Edenkema or God to rule the world and Jesus is a spirit that aids Mame Wata in curing the illnesses of worshippers. In this connection, we can see that Pentecostal Christianity is furnishing this community with a modern institutional space within which to adopt the worship of the goddess. One contribution of this study to the literature then is to expose this phenomenon and to explain that what seems like a paradox is simply the product of an invention.

Also, from the existing literature we do not know much about what worshippers themselves are saying about the goddess. Their voices seem to be absent from the 
authors` accounts. Another contribution of this thesis is that it incorporates what the worshippers are saying about the goddess and what she does for them.

The next chapter describes my research in the field, the setting, and my experiences while collecting the information that went into the writing of the study. 


\section{CHAPTER THREE}

\section{THE FIELDWORK}

A central aspect of this study involved field research. The aim of the fieldwork was to collect data on members of the Christ Deliverance Healing Church, their religious practices and their history as a religious community. I was also interested in learning about narratives about Mame Wata in Half Assini. I conducted the fieldwork during the summer semester of 2008 . The fieldwork involved participant observation and interviews. I also consulted Church documents, files, magazines and books in the library of the University of Ghana. In this chapter I describe the setting in which I did this field study and how I used the methods I have mentioned above to collect the information that went into the writing of this study.

\section{The Geographical Setting: The Village and People of Half Assini}

My main objective in this section is to locate my study geographically. I will describe where the people involved in the study live and how their lives are. This will shed considerable light on their religious lives, on which this study focuses.

Geographically, Half Assini is the last town in the southwestern part of Ghana. It is bordered in the west by Ivory Coast and in the south by the Atlantic Ocean. The original people of Half Assini are Nzemas and they speak the Nzema dialect. The Nzemas are a part of the Akans, the largest ethnic group in Ghana.

Half Assini is one of the hundreds of Nzema villages in the western part of Ghana. Typical of villages in Ghana, many of the houses in Half Assini look old and feeble as a result both of erosion and also of the raw material [raffia stick] used in the 
construction. Presently new suburbs are emerging with state-of-the-art buildings. Half Assini is not far from Axim, the wettest part of Ghana, and has its share of torrential rains during the rainy seasons. In front of some houses are kiosks or sheds covered with branches of oil palm trees. In the daytime people sit here for shelter from the rains and the scorching sun while they sell a variety of items and enjoy the cool breeze from the sea. Houses in Half Assini are normally very large, rectangular in shape, and are clustered together. This is because extended families of two or three or more generations live together in the same house in Half Assini. These houses are often headed by senior sisters or maternal uncles because it is a matrilineal society. Because of migrations to the bigger cities of Ghana, some houses in Half Assini have vacant rooms and people rent out their spare rooms or apartments to "visitors" or people who are not members of their families. Most of the streets of Half Assini are narrow, ridden with potholes and often crowded with playing children, goats, sheep, and chicken that will scamper off whenever they see a vehicle approaching.

Most of the people of Half Assini earn their living from small-scale production and distribution. Many of the men are fishermen and hunters. They leave very early every morning to fish in the Atlantic Ocean and a lagoon called the Abbey lagoon and return at sunset with their catch. The women are mostly traders. Some of them buy the catch from the fishermen, smoke them and sell them in the market. Others buy items from Ivory Coast and retail them in Half Assini or at the market in "Wharf," the busiest trading center in the district of Jomoro, of which Half Assini is a part. There are also farmers who grow corn, cassava, other staples, and vegetables to feed their families. They often sell the rest of the produce to buy fish or meat or pay their children's school fees and to 
buy other household needs. There is a thriving coconut business in Half Assini and many of the young men and women in the village are involved in this business, extracting oil from the coconut and selling it. Most of the oil used by Ghanaian factories in manufacturing soaps and other products comes from Half Assini. A small number of people work in the formal economic sector in government employment and private firms. Other people in Half Assini are self-employed as "fitters," mechanics and hawkers.

\section{The Religious Life of Half Assini}

Half Assini is predominantly a Christian village. There are Evangelical Presbyterian, Anglican, and several Pentecostal churches. One comes across a church building almost every few miles and new ones, especially from the Pentecostal strand of Ghanaian Christianity, spring up every day. People use classrooms, open spaces, and sheds made from oil palm branches as places of worship where they meet every evening. Echoes of preachers using public address systems and worshippers shouting "Amen Amen" can be heard almost every late night. But there are several mosques, too. They are located at Zongo ${ }^{35}$ where "visitors" from Northern Ghana, most of whom are Moslems, live. As is the case in most Ghanaian communities, there is a very strong influence of indigenous Ghanaian religion in Half Assini. The pervasive fear of the anger of traditional gods, ancestors, witches and sorcerers and the importance attached to rituals such as out-dooring [birth rituals] and festivals, reflect this influence. The presence of all

\footnotetext{
: Zungo is a settlement in most towns in Ghana which is composed of Moslems. Moslems are often migrants from the northern part of Ghana. The northern part of Ghana is predominantly Islamic.
} 
of these religions has made Half Assini a very fascinating kaleidoscope of religious activity.

\section{Political Life}

Politically Half Assini lies in the Jomoro district of Western Ghana. It is under the headship of a district assembly. But the political system of Half Assini combines both the modern [western] system of government and the traditional system. The Traditional chief, queen mothers and sub-chiefs continue to play important political roles in the community. They work hand in hand with state law enforcement agents, such as the police, to maintain order. The traditional chiefs derive much power from the religious belief that he is a spiritual head of the people. He mediates between the people and the spiritual world and should be revered.

\section{Social Life}

Half Assini teems with life all year round as there are several community social events -births, marriages, funerals- that bring the citizens home from all over Ghana. But the village is particularly noted for its colorful festivals. Kundum is the most famous of the festivals. It originated around the $17^{\text {th }}$ century and has since then been celebrated annually in August. The festival is an agricultural festival and is associated with the goddess of fertility and is believed to bring bumper harvests of food-stuffs and fish to the village. Another festival called Soh Soh Doh is a local version of Christmas, as it is 
celebrated on the $24^{\text {th }}$ of December to prepare for the birth of Jesus. It is said that "No son or daughter of Half Assini misses Soh Soh Doh. ${ }^{36}$

\section{Participant Observation}

Participant observation for this thesis involved making trips to the religious activities of the community. Because I did not stay in the field for a long period I was able to participate in worship with the community only three times. During my visits I made much effort to observe and understand the significance of the rituals for the members and to establish rapport with them. I recorded my observations during these visits in a field note book that I carried along. Normally I would hang around with members of the community and engage them in conversation after the rituals were over. In this way I was able to make some friends who became my regular informants. On occasion, I would join members in their after worship "chats." I had observed that members clustered and conversed in groups, and I felt that joining such conversations would be a good way of learning more of their personal views and experiences. So that they would not feel I was merely eavesdropping on them, I tried to be part of the chats, especially when the topic was familiar to me. But my status as a "daughter of the village" made it easy for me to be part of conversations, in that, it provided me with experiences to share whenever such issues cropped up.

\footnotetext{
${ }^{36}$ The "Soh Soh Doh" was initiated by a group of ten men called "the Big Ten" in the late 1970s. Three of my uncles played a great role in its origins.
} 


\section{Interviews}

I conducted some interviews, too. The aim of the interviews was to collect information on members' views on Mame Wata and their experiences of her. I conducted some interviews during my visits to the community's rituals at any time it was convenient, that is, during worship, during interludes, after worship and while we were walking home after church. But I also interviewed worshippers in their homes and at their work places, especially the market where some spent the entire day selling their goods. My interviews were actually conversations in that they were mostly informal and unstructured. I was guided by an interview guide that included questions covering the range of topics I was interested in. Because I did not religiously follow my interview guide, interviewees had more control over the interview situation. The longest interviews lasted from forty minutes to about one hour, and were conducted mostly with the leaders and the priest on days when they were not very busy in the church building. Shorter interviews often lasted about twenty minutes or less and were mostly conducted with lay members during or just after worship. I made a number of follow-up interviews, too, by going to followers' homes and work places. These were mostly for purposes of seeking clarification on issues we had discussed sometime earlier in the temple.

In my interviews with the leaders I asked them questions about the community`s origins, history, and their teachings. Interviews with lay members delved more into personal and social issues, such as why and how they joined the community, how they felt about the group, and their experiences of the Goddess's power. Since Mame Wata is believed to be in the sea I visited two fishing communities living along the shores to investigate what people knew and said about the goddess. Though most of the 
members of these communities did not belong to the religious community I was studying. by listening to their stories I learned something about the popular views about the goddess floating about. Some of my conversations were taped and transcribed. Some people. however, did not feel comfortable having their conversations on tape, so I would carefully listen to them and then quickly write out the entire conversation in my notebook as soon it was over so that I would not forget the details.

Lessons from my field research course at Florida International University helped me in the course of doing my interviews. I always probed extensively. If I came across what seemed like inconsistencies I would comment on my curiosity and seek the help of the person in sorting these out. I was patient and careful not to interrupt with questions when someone was talking. lest this would distract me from listening and the interviewee from talking and affect the flow of our chat Always I waited for every detail they might share. But I was persistent and relentless in my pursuit of information. I listened carefully. was attentive, pensive, and expressed great interest in all aspects of their stories. Often I would ask them to explain further an earlier point whenever they would pause. At the end of each interview day I would read over my notes and fill in the missing details.

\section{The Experience of the Field: Going home}

Even though I was going to do ficldwork in Ghana. my trip was not the typical fieldwork trip. I was already familiar with Half Assini because it is my hometown. Furthermore. personally, the reason I was going to Ghana was not only academic. I had 
been away studying in the "white man's" ${ }^{37}$ country for a year and I was returning to Ghana to reunite with family and friends. So, I was indeed going "home" and in preparing for the fieldwork I considered this factor and its implications seriously.

In Ghana traveling abroad drastically changes people's perceptions about you. In the imagination of many Ghanaians "aburokyiri" [generic term in Ghana for all the rich northern American countries] are places where life is easy, where people have wealth and there is a large quantity of food and other "good" things. ${ }^{38}$ Traveling to "Abrokyiri" could therefore raise a person's social status in Ghana. More importantly the "been to" 39 is expected to come back with items from the white man's land, especially American dollars, Western-style clothes, gadgets, etc, all of which are assigned a high value. Also, giving gifts to relatives when one travels is considered to be courteous in Ghanaian culture. Coming from the USA, which is considered in Ghana to be a rich country, I knew people would expect gifts from me so going back home meant doing shopping for family and friends to "exonerate" $"$ the image the U.S had in Ghana.

I arrived in Ghana at $8: 30 \mathrm{pm}$ local time and my fiancé and my cousin who works with the immigration service and is stationed at the airport came to meet me. My arrival was momentous. Everyone was excited to see me. That evening we had dinner together

\footnotetext{
"I I used the term, "white man's land" as used in Ghana to describe Europe and North America.

${ }^{38}$ The behavior and mannerisms of Ghanaian people who emigrated to North America and Europe reinforce these notions. They display wealth and opulence and show signs of the "good life" associated with living in these places. For instance they send money [dollars and pounds sterling] to relatives frequently, drive in flashy cars, and build beautiful houses when they return to Ghana. The image Ghanaians have about those who travel abroad is that of good life. They expect everyone who travels abroad to exhibit that lifestyle.

${ }^{39}$ One who travels abroad.

40 The word exonerate as used above is meant to act in line with their perception to exonerate the US.
} 
amidst conversation of my flight back home and Miami, which is very popular in Ghana because of the Spanish telenovela (love stories) soap operas. I had to answer a dozen questions about Miami Beach and the activities that go on there. My journey to Half Assini was the happiest of all because I was going to see my parents and grandparents and the rest of the extended family.

\section{Renegotiating My Entry}

Because I come from Half Assini, going back to do field research there was quite easy. I had established acquaintance with the priest even before coming to study in the USA and he became my gate-keeper in that he re-introduced me to the church and told members that they will be seeing me around and I will be "going about asking questions". "When you see her, see her as someone who has come to get information so that she can correct the negatives labels that society has against you," he said to them on the first day I was at worship with them.

I noted, however, that because of my "been to" status both the priest and the members of the church viewed me differently sometimes. They seemed to regard me highly. They would say "it's not easy to study in a foreign land, you have done well". At one time the priest asked me, with some concern, how I was able to follow my white professors in the classroom. I had to explain to them that it was just a matter of time and one becomes used to the faster way of speaking. 


\section{Some Challenges}

Getting access to information was not always easy. The priest as well as some members of the Mame Wata church gladly and freely volunteered information with no hindrance, but there were some members who wanted to be convinced that I was not a spy before granting me audience. The fishermen especially were very wary of talking about the goddess. They said she was the one that put fish in the sea and ensured a bumper catch and that talking about her could lead to a poor harvest or accident on the seas. Most of them therefore declined to talk about her initially but gave tidbits later. Sometime the members scheduled meetings with me and never honored them. Or when I went to them they will simply say "I am busy today; come tomorrow," and name a time. But when I returned to their homes at the stated time they had gone to the markets or farms.

On the whole it was a good experience. I left the field quite happy to have gathered enough of the information I needed to complete my thesis. More importantly I discovered some new themes I could work on for my $\mathrm{PhD}$. I took the phone numbers of most of the members and the priest in order to contact them in case I had to. In the next chapter I turn my attention to Nzema traditional religion, which had a very strong hold on the people of Half Assini in pre-colonial times. My aim is to explicate the role of women and their place in this religion. 


\section{CHAPTER FOUR}

\section{THE NZEMA TRADITIONAL RELIGION: THE PLACE OF WOMEN}

I am an Nzema from the village of Half Assini in western Ghana. For this reason, there is a sense in which I can say that this study is about us. I am a part of the story of the women I want to tell in this study. In this chapter, I introduce my readers to the Nzema people, focusing particular attention on our indigenous religious beliefs and the place of the female in our religious thinking and action. The reason I feel this discussion is important is that religious beliefs greatly inform how the Nzema understand their world and respond to it. Religion also reflects what they think about their society, the universe, and the things that happen around them. It follows then that any attempt at understanding these people, especially the females, who this study is about, must pay attention to their religious beliefs and the actions that stem from these.

The discussion will begin with an introduction to the Nzema people. Because the study is about women I will follow with a description of the Nzema indigenous religion stressing the place of the female in this religion. Here I will argue that the place of the female in Nzema religious thinking is a reflection of how the society perceives her power and her role in its success. I will describe how the coming of Europeans and the imposition of colonialism and Christianity affected how society saw the female and led to a decline in her powers, setting the stage for a reconstruction of ideas about her in post colonial times. 


\section{The Nzema}

The Nzema are part of the largest ethnic group in Ghana called Akan. They speak Nzema and occupy the extreme south western part of Ghana extending in some places beyond the border into Ivory Coast. Some Nzemas live along the Atlantic coast and others in the forest belt bordering this coastline. Traditionally they were farmers and fishermen. In Nzema traditional community there is no separation between the religion and society. They are intertwined.

Nzemas have a worldview that is shared by all the Akan-speaking people of southern Ghana. The universe, Nzemas believe, is essentially a spiritual space. Though they acknowledge the existence of a natural or material world they say that this material world is connected to the supernatural and manifests the supernatural. More importantly the Nzemas think the natural universe is dependent on the "supernatural" for sustenance. This is so because in Nzema thinking a host of beings, spirit beings, exist in the supernatural world that control events in the natural world. These beings exist in a hierarchy. At the peak of the hierarchy is Edenkema Nyamele, ${ }^{41}$ or the Supreme Being or God. He is the creator of the universe. Following him being are the deities or the gods collectively referred to as awozonle. ${ }^{42}$ These include the sky gods and the earth goddess [Azele Yaba]. The ancestors or spirits of the dead, referred to as the Nananom, come next. Impersonal spirits or forces, mystical forces and beings and their human agents [witches, sorcerers], ordinary humans and natural objects, and natural phenomena are located at the base of this spiritual hierarchy.

\footnotetext{
${ }^{41}$ Edenkema literally means 'he who was there before others' or in the ancient of days. It is an appellation used in addressing Nyamele or God.

42 Awozonle means gods in Nzema. The singular is bozonle.
} 
The Nzemas believe that the host of spiritual beings outlined above affect their lives positively or negatively. These spirits are moral agents and dislike violence, curses, lies, dishonesty, uncleanliness, impurity and persons who infringe taboos. ${ }^{43}$ They reward the good and the obedient as well as punish evil people and those who go against their precepts. Members of society must follow rules and regulations of society because they are sanctioned by these spirit beings. Humans must make sure not to offend or displease the spirits with their actions and behaviors. ${ }^{44}$ Furthermore, because human beings are next to last in the hierarchy, they have less spiritual power. This makes them vulnerable and leaves them with no choice than to succumb to the will of the other spiritual agents in order to survive. This situation generates among the Nzemas a sense that they live in a universe that is essentially "a dangerous and mysterious place" and that to survive in it they need constant supernatural fortification, which is achieved through alliance with a supernatural agent. How God and these spirits affect humans depends on how humans conduct themselves. When a person offends a god the wrath of the god is often evident within a few days. Sometimes a person is warned after the act, but he/she is punished if it becomes persistent.

The Nzema peoples' worldview form the basis of their indigenous religion and this informs their day to day activities and ritual practices. Men and women practice and live their cultural traditions whether they are Christians or Muslims. They still remain Nzema and consciously or unconsciously adhere to the beliefs and practices of the land. In recent times, however, with the onslaught of globalization and new ideas flowing into

\footnotetext{
${ }^{43}$ Vinigi L. Grottanelli, "Gods and Morality in Nzema Polytheism," Ethnology Vol. 8, No. 4. (Oct.1969), 381.

44 Grottanelli, 381.
} 
Nzema sociality, life is rapidly changing and the 'traditional fabric' is said to be getting weaker. But I maintain that its influence is still there and that the older generations especially are finding innovative ways of transmitting their inherited cultural values to the coming generation. Having introduced my readers to the Nzema and their religious worlds, I shall now turn to the place of women in this religion.

\section{Women in Nzema Religion}

Women have always occupied important positions in both the social, religious and political setting of African societies and the Nzemas are no exception. In what will follow I will describe religious beliefs that celebrate the power of the female in pre-colonial traditional Nzema societies. The goal of my description here is to show that these beliefs reflect the Nzema society's acknowledgement of the central role of the female in its success. The discussion will also show how the powers of the female dwindled with the coming of European missionaries and the establishment of Christianity in Nzemaland. I will conclude with a brief discussion on the Ghanaian experience of globalization and how this situation is creating conditions that call on communities to go dig into their past for answers to new problems. This is the social and political context in which the women in this study are returning to old notions about the power of women and relying on Mame Wata, the goddess who personifies these ideas, for the strength to go on.

\section{Nzema Women}

The Nzema Akan society is a matrilineal society in which women have always wielded considerable power and influence. As mothers, women are viewed as the givers 
of life, the originators of communities, and the sustainers of the continuity of communities. As wives Nzema women are literally the hubs around which nurturing and other aspects of domestic life revolve. Nzema women control trade through their petty trading activities and through them wealth and prosperity flows into the community and households. As sisters, aunts, and daughters, Nzema women occupy other spaces in society within which they demonstrate and influence power in a variety of related ways.

Religion in African societies provides people with a language that they use to express their realities. For the Nzema, society's appreciation of the crucial roles that the female plays in society finds expression in a variety of religious beliefs featuring and celebrating the power of goddesses.

\section{Women and Spirituality in Nzema Traditional Religion}

In African societies indigenous religious beliefs do not come from any individual to whom they were revealed by a divine source. Rather they follow from the observations that individuals make about their own experiences and happenings in their social worlds. I argue here that religious beliefs about women, be they humans or goddesses, are reflections or idiomatic expressions of the socio- cultural roles that they play. A positive socio-cultural evaluation of how indispensable the female is to success of Nzema societies as I have indicated above, finds expression in a number of beliefs celebrating their spiritual power and in what follows I will describe some of these beliefs. 


\section{God as Female}

Though Nyamele or God is presently described as a male among the Nzemas, in the past there was a female aspect to this being called Obaatampa in Nzema religious thinking. Some oral sources suggest that she is the wife of Nyamele. It is said that after Nyamele created the universe it was Obaatampa who nurtured all creatures. She continues to nurture and to give abundantly without the aid of Nyamele. Sometimes this female dimension of God is emphasized more than the male aspect. A libation prayer goes: "Eradane kpale, mame mo oma amaa aleye [mother who gives food], Mame mo abo ama awo bane [mother who protects], Obaatampa." Literally this can be translated as "the ideal woman who knows what her children would eat and provides for them without their asking. The woman, who clothes her children, takes care of them and protects them when they are ill." The providential aspect of God in this prayer is described in terms of a female. Linking the providential aspect of God to the female for me reflects society's view of the female as the nurturer--the caretaker and provider of material and emotional support to children and husbands both in homes and larger society.

\section{The Female is Earth}

Furthermore, the Nzemas describe the earth, without which human life is practically impossible, as a female spirit called Azale Yaba. Azele Yaba is sometimes referred to as abrewa or "old woman." Azele Yaba ranks next to God and is in a class of her own as she is not an oracular deity like the other lesser deities [awozonle, singular bozonle] whom people may consult in times of crisis. As humans are essentially created with clay in Nzema religious thinking, it is said that Azele Yaba is the one from whom 
humans emerge. Also, her bowels are the final resting place of humans. Thursday is a special day set aside for her and on these days there is no tilling of the land because she is resting. Severe punishment was meted in the past to whoever infringed this taboo. Azele Yaba is also the custodian of morality. She is a keen upholder of truth and whenever the veracity of a statement is in doubt the person who made the statement is challenged to touch the tip of his tongue with some earth to prove that he/ she is telling the truth. Azele Yaba abhors the spilling of human blood. Wherever murder occurs, she has to be appeased. When angered, Azele Yaba becomes a killer mother who unleashes untold calamities on a community. This view reflects the place of the mothers as the primary transmitters of moral values in Nzema homes and society, who do not hesitate to unleash the severest form of punishment such as spanking, denial of meat, or peppering of the buttocks of recalcitrant children.

\section{The Female Body}

In Nzema society female blood has spiritual significance. It is viewed as an important spiritual source of life. The material body of a person, it is said, is composed of the blood of the mother. In the creation of a human, Edenkema Nyamele donates a soul that is the source of breath. a father donates a spirit that determines the person's personality and a mother donates the blood [or body] which encases all the other elements and without which a person cannot function. The mother's blood also glues community members together as brothers and sisters in a matrilineal Nzema society. This is because the members of the Nzema clans claim their ties as brothers and sisters 
because they have their mother's blood flowing through all of them. They are held together as one group by their common affiliations with their mothers.

Also, female blood is said to have superior spiritual power that can neutralize other supernatural power sources. Thus a ritual specialist must not come near a menstruating woman lest his power would be drained by the menstrual blood because of its higher potency. Even the vagina has a special spiritual significance, according to Nzema beliefs. This is where all life begins and also the "door" through which humans pass as they descend from heaven to earth to begin their lives as babies. For this reason the vagina is considered to be a sacred. It can only be mentioned in pseudonyms and never directly during conversations. It is also said that if Edenkema equipped the vagina with powers to create life, he also gave it powers to protect life so the vagina is considered to be endowed with medicinal properties. The urine of a female because of its contact with the vagina has the power to heal and neutralize the effect of evil charms.

In pre-colonial times the spiritual power of the female was pressed into service to ensure the security of the state during war. Obeng and Achempong describe the ritual of "mmomomme," a distinct type of spiritual warfare involving the use of female power among Akans, of which Nzemas are a part. ${ }^{45}$ According to these two authors, while the men were on the battle field, the women in the village would chant, daily marching in partial nudity [exposing their vaginas] from one end of the village to the other, until the soldiers, their children, returned. This ritual was meant to protect the soldiers at war

\footnotetext{
45 Emmanuel Akyeampong and Pashington Obeng, "Spirituality, Gender and Power in Asante History," The International Journal of African Historical Studies, Vol 28 No. 3 (1995), 492.
} 
mystically. Sometimes the rituals involved the partially nude women pounding empty mortars with pestle as a form of spiritual torture of the state's enemies. ${ }^{46}$

\section{Women, Power and Water}

There is a strong affinity between the female and water in African Religious beliefs. Goddesses are often associated with water bodies. For example in Nzemaland goddesses such as Egyake Bula, Awiane Aluanu, Amanzule, Bula Adwoba, Gbgogbo, Mansa and Mame Wata ${ }^{47}$ have their homes in water bodies. Beyond Nzema, others such as Oshun, Yemaja, Olokun, Erzulie, and Lasiren are all associated with water. This affinity, I argue is another African social commentary about how indispensable women are in society and how society originates from them as mothers and depends on them for success in political, economic and social life.

In Nzema thinking, women's roles in life can be compared to those of a river, a stream, or a sea. Both women and water sources are the originators of human communities. Just as women originate a person's life by giving birth, so are the beginnings of towns and villages determined by the presence of a water source. As nurturers of life, women are just like water upon which society depends for their sources of food to grow. Just as water cools and calms the body on a very hot day or is a softening agent, so do women contribute to the peaceful coexistence of members in homes and in larger Nzema society as the crucial mediators and negotiators during

\footnotetext{
46 Akyeampong, 494.

${ }^{47}$ Komenle Somiah Nyamekeh, Half Assini, 07/ 11/08. Komenle means priest in Nzema. Somiah Nyamekeh is a traditional priest in Half Assini and the president of the "Psychic and Traditional Healers Association" of Jomoro District.
} 
conflict among individuals or groups. Just as the sources of wealth through trade are the water bodies that enable traders to travel back and forth, so are women petty traders the avenue through which wealth flows into the Nzema community. Just as the security of a community is threatened when its main sources of water dry up or when there is a flood, so will the Nzema community be threatened with chaos should women stop playing their roles-giving birth, providing sex for husbands, taking care of the home, trading etc. The power of women is comparable to that of water and that is why most female deities are associated with water in African religions. The point of the discussion so far is to demonstrate that indigenous Nzema beliefs about the spiritual powers of women reflect how the Nzemas appreciate women's roles in society.

I will add that not only is a woman's roles appreciated and celebrated through beliefs, she is feared because of her powers. I will even argue that the belief that women are witches is an expression of the fears societies harbored about them, and the mystery that surrounds them on account of their power. Furthermore, it is on account of this belief in their innate spiritualities that women in pre-colonial Nzema were charged with the crucial task of ensuring the health and security of the community as healers and midwives and also preparing the body of the dead for the journey to the ancestral land. Also, in pre-colonial Nzema society women occupied the high political position of chief or king maker. A select group of women chose chiefs. These are the queen-mothers and elderly women. They act in consultation in a clan to elect the chief. This group of women also had the power to de-stool a chief. They did so by simply removing their "saale",48

\footnotetext{
${ }^{48}$ Saale is a piece of cloth worn like underwear traditionally.
} 
and slapping a chief's face with it in public. ${ }^{49}$ These practices and the importance of the Nzema women would, however, decline with the onset of colonialism and in the next section I shall describe what precipitated this decline.

\section{Colonialism and the Decline in Nzema Women's Power}

With colonialism, came Christianity and the introduction of western gender ideologies into Nzema society. An andocentric Christian religion that recognized and celebrated the male and men within its ranks replaced the feminine principle in Nzema religion. Nzema women were removed from the socio-religious locations, where they had exercised power in the pre-colonial religious order.

The Portuguese were the first to come to Ghana, then referred to as the Gold Coast, to trade. As Christians they came with their religion. They arrived in Elimina ${ }^{50}$ towards the end of the $14^{\text {th }}$ century. They built a Fort in 1482 at Elimina and named it São Jorge da Mina de Ouro [St. George of the Mine Castle] and another Fort de Santo António de Axim, in 1486. Axim is along the coast and one of the biggest towns in Nzemaland. Presently it is about forty minutes drive away from Half Assini. The original motive of the Portuguese was trade, but as Catholics, they came with their chaplains, who felt that, to have smooth trade there was a need to evangelize the locals. This was the beginning of Christianity in Ghana by the Portuguese traders. This earliest attempt at Christianizing Ghana was however not successful.

\footnotetext{
${ }^{49}$ Sam K. Akesson, Traditional Beliefs and Customs of the Nzema People. 1950; unpublished; found in the archives of the Western Regional House of Chiefs.

${ }^{50}$ Elimina is in the central region of Ghana. It is a historical town.. The first Europeans who came to Ghana built their first castle and settled there. The Europeans named the town "El Mina" meaning a mine of gold.
} 
Two streams of missionary activities would follow this attempt. ${ }^{51}$ The first stream of missionaries came after the Portuguese in the fifteenth century and used the forts and castles built by the Portuguese for their activities. They were the Augustinian, Capuchin, and Dominican Friars. ${ }^{52}$ But this attempt also failed as the locals were unresponsive to the missionary initiatives. In the nineteenth century the second stream of western ${ }^{53}$ missionaries also came to Ghana. These included The Wesleyan Methodist Missionary Society (WMMS) $1813,{ }^{54}$ the North German Missionary Society (Bremen mission) $1847, .^{55}$ and United Free Church of Scotland $1914 .{ }^{56}$ This time their attempts yielded positive results.

In Half Assini, Christianity began in the 1900 s and was represented by the presence of the Methodist Church. As part of the evangelizing strategy, the church took some young men to train abroad, built schools, vocational centers, and introduced new ways of agriculture and other infrastructure into Half Assini.

The missionary-established churches also introduced the idea of God as a male, which replaced the Nzema bisexual notion. This male God had exclusive power and usurped the function of lesser beings, some of the most significant or powerful of whom

${ }^{51}$ Cephas N. Omenyo. Pentecost Outside Pentecostalism: A study of Charismatic Renewal in the Mainline Churches in Ghana (The Netherlands: Boekencentrum Publishing House.2006), 42.

${ }^{52}$ Omenyo,, 42.

${ }^{53}$ Western here includes United States and Canada.

${ }^{54}$ Omenyo, 57. It was founded in England by the Methodist church with the aim of evangelizing abroad. A group of young Ghanaians formed a bible study group. The group had branches in Cape Coast, Anomabo and Discove. They later wrote to the WMMS to send someone with bibles. The WMMS later came to Ghana as a follow-up to do missionary work.

55 J.K. Agbeti, West Africa Church History: Christian Missions and Church Foundations 1482-1919. Vol. 22. No 1 Leiden: E.J, (1989) 81.

${ }^{56}$ Omenyo, 61. 
were goddesses in Nzemaland. Within church rank, men exclusively held positions of power and authority as clergymen and catechists. This is because Christian theology was developed by those in power and these were European. They wrote theology, and were the heads and preachers in the churches and put their stamp of authority on women. Beauvoir argues that "one is not born a woman; one becomes one," Women became "the other defined by men and patriarchy and consequently they are less than fully human. ${ }^{57}$ This European development was transplanted into Africa and Half Assini was no exception. In the synod and district councils, men occupied the seats. Positions of priest belonged only to men in colonial Christian Africa. The feminine standard in African religion began to experience a decline.

Furthermore, the structural changes that were introduced by the imposition of colonial rule resulted in women being dislocated from the socio-economic spaces they had occupied as traders, owners of lands and farms, to name only a few, and placed them in domestic roles where they lost the power they hitherto held in society. Christianity also introduced modern medical practices and facilities which replaced the need for traditional healers and midwives, roles that women had been charged with filling in pre-colonial times. Male-controlled Western-originated medicine attempted to supplant the need for rituals and sacrifices the women had previously undertaken for the welfare of their communities. My point here is that colonialism resulted in the loss of women's influence in both the social and religious worlds of the Nzema.

\footnotetext{
${ }^{57}$ Simone de Beauvoir, The Second Sex, Trans, H. M. Parshley. (Penguin 1972[1949]), 46.
} 


\section{Post-Colonial Nzema}

Beginning in the 1960s, however, in communities all over sub-Saharan Africa women began to reclaim some of the ground they had lost in religious landscapes. The independence of many African nations from their European rulers encouraged this development. In Ghana, which attained independence in 1957, the efforts of women to take back their indigenous religious roles resulted in the rise of spiritual churches, the majority of which originated as break-away groups from missionary Christian churches. In the establishment of the African-established spiritual Churches, women were founders, priests, and prophets. ${ }^{58}$ Not only were these groups led by women, but the followers were also largely women and the focus of the new groups was mainly on the health and other material needs of these women and their families. More recently, globalization is providing yet another opportunity for women to consolidate the spiritual gains they made in the 1960 s. I turn to this process in the next section.

\section{Globalization and the Present Situation}

Globalization and the increased contact of Ghana with the West, especially America, are creating new conditions that are calling on the Nzema to reach even further back into their past for answers. As a cultural process, globalization is not new in Africa. It has always been there due to the European trade, exploration, and colonization of Africa. Globalizations, I suggest, began in Ghana during the colonial era when Ghanaians were introduced to western education, dress, food, system of government and religion. There is, however, something different about the present process in Africa. Worldwide

\footnotetext{
58 Olupona, xviii.
} 
changes in business and developments in communication technology and transport are speeding up the rate at which humans, goods, and ideas move from place to place. ${ }^{59}$ Through the electronic media, every community in the world is able to experience happenings at one place simultaneously. Territorial distance and borders are now of limited significance and the world is now a single place. ${ }^{60}$ When I use the term "globalization" this present form is what I mean.

One other thing about globalization, in Ghana especially, is the leading role of America in the process. I will say that what is happening in Ghana is "Americanization" because American popular culture especially, but also other ways of life, are being rapidly implanted in Ghana. This influence can be measured in terms of American style and taste in the areas of politics, economics, communication and social life. ${ }^{61}$ But as the world draws closer, people are negatively or positively affected by other people and Ghana is no exception. Some challenges associated with globalization are creating conditions conducive for the rise of a particular kind of religious activity in Ghana and the religious experiences of the women in this study can be understood in this context.

First, lifestyles and values from the West are undermining traditional lifestyles of Ghanaian people, their values, morality, and other aspects of their lives considerably. For example, nowadays Ghanaian people increasingly examine life from a strictly economic standpoint, influenced by capitalist ideas. People now aspire to the lifestyles of the American "rich and the powerful" in dress, dietary habits, and housing. They focus their

\footnotetext{
59 James Clifford. The Predicament of Culture (Massachusetts: Harvard University Press, 1994), 15.

${ }^{60}$ Clifford, 15.

${ }^{61}$ Birgit Meyer and Peter Geschiere, Globalization and Identity of Flow and Closure. (Oxford: Blackwell Publishing, 1999). 1.
} 
efforts and energies on acquiring commodities: building state-of-the-art houses, driving in expensive cars, and having a lot of money, mainly dollars. Many Ghanaians now measure success largely in terms of a person's ability to follow trends in global fashion [especially American], to adopt American lifestyles, mannerisms and habitual traits. This new situation has introduced new goals in Ghana that only a small number of people--the well to do, powerful public officers, expatriate workers, wealthy businessmen and businesswomen, and people whose relatives live abroad or who themselves live there-can achieve. For the majority reaching these goals remain a dream they can never realize. They have remained, and a constant sense of failure haunts them, making their poverty seem unbearable. These challenges, viewed from a traditional Ghanaian worldview, are mostly experienced in terms of witcheraft and demonic activity and have triggered a frantic search among ordinary Ghanaians for spiritual power and human agents who have it and can use it to protect them or ensure their material well-being. This is why new churches, especially Pentecostal ones, are rising in Ghana and their leaders are becoming popular.

Specifically these challenges are affecting women more than men both because women were already marginalized in many areas of modern life in Ghana, and because of the responsibilities they retain for rearing children. For these reasons, in spite of the andocentric notion of God that the churches that are rising espouse, women are at the fore in the search for spiritually redemptive symbols from them. In fact, the majority of followers of the Pentecostal churches are women.

There are some people, too, in Ghana who feel that in the face of the overwhelming influx of western values, traditional Ghanaian values, beliefs and practices 
will vanish. The fears of losing one's tradition and the nostalgic feeling for how things used to be are making such people invent as well as revisit what they had. The women in this study fall in this category. For them a female symbol of spiritual power holds a strong appeal. But this appeal is a relic of their past. This is because, as I have demonstrated above, the female principle in religion has been a very strong element of Nzema indigenous religious traditions. Western feminist ideas which float around in all societies in Ghana nowadays have also contributed to the rekindling of this interest in a symbol of feminine spiritual power among these women.

A wave of feminist consciousness originating from the West, but sending ripples all over the world, has caught up with the Ghanaian women too. This wave is giving new meaning and a sense of urgency to women to act to improve their situations. It all began when the commission on the Status of Women (CSW), established in 1946 by the U.N. Economic and Social Council to promote the rights of women in political, economic, civil, social, and educational fields, successfully lobbied the United Nations General Assembly to declare 1975 the International Women's Year. At the first World Conference on Women, held in Mexico, it was recommended that 1976-1985 should be declared the decade for women. This decade sought to address the needs of women all over the globe in matters relating to equality, peace, and development. Ghana was one of the African nations to respond promptly to these initiatives. In 1975 the most popular governmental organization of women, the National Council on Women and Development (NCWD), was established to serve as the official national machinery for advising the government on all issues related to women in Ghana. 
In 1991, the $31^{\text {st }}$ December women's group was created, led by Nana Agyman Rawlings, wife of the president of Ghana at that time. The climax of this rising wave however was the Fourth World Conference on Women in Beijing in 1995. That year, for the first time in her history, Ghana sponsored a delegation of women to the conference. What followed this conference was a new awakening among many women in Ghana. The rallying slogan was "What men can do, women can do better". The expression "after Beijing" also emerged. It was used by women to signal the need for change in their own attitudes regarding gender issues. For example in claiming or reclaiming their rights to property, status or other positions, women would often say "this is the after Beijing era," or "we are in After Beijing" to signal the need for a change in attitudes. Encouraged by these developments, a number of NGOs began to emerge in all parts of Ghana organizing women in different spheres of life. Groups such as the Progressive Women's Credit Union rally women and help them to obtain inexpensive loans to initiate businesses. Others, such as the West African Media Network [WAMNET], expose injustice against women in society. Another group, Women in Management Resource Center [WIM] works to achieve economic independence of women and alleviate poverty at the grassroots level. ${ }^{62}$ These are just a small number of NGOs currently actively engaged in empowering women in Ghana. Branches of these groups are in Half Assini actively rallying women, educating them on issues such as the importance of women's education, the need to be independent, the need to be assertive and to fight for their rights. They are also encouraging women to be involved in regional and national politics. One of such

\footnotetext{
62 Agatha, Zaakpa. "Women Organizations in Ghana."[ website and database]. 3/01/07. Available from http: www.distel.ca/womlist/countries/ghana.html. Accessed 10/10/08.
} 
outstanding women--Hawa Yakubu--died recently. She was a member of parliament. She singularly traveled the length and breath of Ghana, educating women on the need to participate in politics, both at district and national levels. Her slogan was "women arise." She was of the view that women are more than the men so when they engage in politics, they can push through policies that benefit women, such as programs opposing domestic violence and female genital mutilation. This is the socio-political setting within which the quest of the women in this study to identify with Mame Wata, a symbol of female power must be understood. Around her, the women are digging into their pasts and revamping elements of the indigenous ideas about the spirituality of the female in direct and symbolic ways. They are also reading into this figure new and foreign religious meanings and feminist ideas floating around, and they are using these meanings to get around their modern challenges. To conclude, I have tried to argue that the Mame Wata healing church in Half Assini, called the Christ Deliverance Church, but which focuses on the female Wata goddess and whose following is largely women, is a manifestation of Nzema women reclaiming their lost spiritual roles in a rapidly globalizing Ghana. In doing this they have been driven by their daily challenges and inspired by western ideas about the powers of the female, all of which are associated with globalization. They tap into the powers of the local goddess to solve evolving problems and they do so with the traditional belief in the power of the feminine symbol. 


\section{CHAPTER FIVE}

MEMOIRS OF THE CHRIST DELIVERANCE CHURCH'S ORIGINS:

\section{CHARISMA AND THE INVENTION OF A RELIGIOUS COMMUNITY}

The Mame Wata healing churches are found mostly in the Jomoro District of the Western Region of Ghana. Individual priests and priestesses lead these churches. The Christ Deliverance church, which is the focus of this work, is one of these. This church emerged in the late 1970s and is situated on the outskirts of Half Assini on the way to the border post between Ghana and Ivory Coast. There is a bigger branch in Ivory Coast, but this study will focus only on the one in Half Assini. In this chapter I will demonstrate the role of a charismatic personality, Jerome Agyimah, in the founding of the Christ Deliverance Church. I will report stories I heard from the community and the village of Half Assini which show that the followers believe the founder is an agent of Mame Wata, the goddess. and that they have faith in his powers because of this belief. I will argue also that even though to the founder and the followers Mame Wata is essentially a goddess, she is also an embodiment of pre-colonial Nzema ideas about female power and its crucial role as the foundation stone of this matrilineal community. In African communities, religious beliefs are sometimes avenues through which people express what they fear or desire, or experience around them. The belief in the powers of Mame Wata and her role as the source of the powers of this founder, I will argue, is another way for this community to express the idea that women, too, are sources of personal and social power. 


\section{The Founder and the Founding of the Community: The Stories}

The founder of the Christ Deliverance Church, Osofo Jerome Agyimah, is a highly respected man in Half Assini. Non-members as well as members of the community revere him. But access to him is not easy as he lives in Ivory Coast; Ghana's neighboring country to the west. Because my stay in the field was short, it was not possible for me to travel to the Ivory Coast to interview Agyimah about the origins of the community. A chance encounter with his uncle, however, provided a good opportunity for me to learn not only about the origins of the church but also the circumstances surrounding the founder's birth, all of which contribute to the belief that he is endowed with powers of the goddess. That day, I had gone to the community's compound hoping to meet the priest in charge, when I met instead the uncle of the founder, Egya Adjalou. $\mathrm{He}$ is a middle-aged man and also a member of the church. Even though I was disappointed that I could not meet with the priest, I felt that this encounter with Adjalou might give me the chance to learn something very personal about the founder, given the fact that Adjalou was his uncle. I seized the moment to ask questions. We sat on the opposite ends of a wooden bench under a tree in front of the church building, my tape recorder on and in my hand. "It was an experience with Mame Wata that started everything," he said, taking his shirt off and using it to fan his bare chest. We had just exchanged greetings and I had told him about my research. "When he was born, he was called Kodwo, but later he became Osofo Jerome Agyimah .... He changed his name only after he became a priest. Mame Wata chose him to be her mouthpiece even when he was in his mother's womb", Adjalou went on. "But how would you know that?" I interrupted him, excited about what he had just said. He paused briefly as if he was 
wondering where to begin, and then started into the story of the mysterious circumstances surrounding the birth of the founder-all of which pointed to his not being ordinary. "His mother and father were both farmers. They would cross a river to their farm every day. One day, as they were returning from their farm, something strange happened," he continued the story. "What happened?" I urged him on, seeming rather impatient. "A strange looking fish jumped into their canoe and. being very much afraid. they quickly threw the fish back into the river. Not long after this the fish jumped into their boat again." "Ei" I exclaimed, in surprise. "Yes," Adjalou reassured me and continued the story. "Again they threw it back. When for the third time the fish jumped into their canoe they decided to take it home and to inquire from the traditional priest why this was happening to them. The traditional priest then revealed that the woman was pregnant and the child to be born would be a great person and that the fish episode was a sign. He also said that they must cook the fish and eat it..... And when they cooked the fish and ate it, a bond was established between the fetus and Mame Wata who the fish represented. This is why I am telling you he was chosen by the goddess from the womb of his mother. "Ahaa," I said, nodding my head. As a child growing up in Half Assini I had heard versions of this story, but they were never as clear as Egya Adjalou was telling it to me.

Egya Adjalou also told me of the founder's childhood, stressing how he distinguished himself from other children - all of which he interpreted as indications of his special connection with the goddess. "As a child he was perfect! He did the right thing all the time. But it showed, too, that he was spiritually inclined," Egya Adjalou said. "What things did he do?" I wanted him to elaborate. He continued: "He could see things in the spiritual realm, so sometimes he would caution us about passing at a particular 
place in the town. Sometimes he would just hold your hand, press on it very hard and tell you to be careful about certain people or when doing certain things. Then he had this strange behavior...He would dress like a girl and behave as one. He was never attracted to the opposite sex. He never dated, as a young man. As a matter of fact he has never had any sexual relationship with any woman."

What Adjalou was telling me was not new to me. Before this interview I had heard similar stories about how the founder was different from other children as a child. It was said that he was so talented and he excelled in everything he did. According to one story when Agyimah, the founder of the community, was a boy he could score as many goals as he wanted when his school team competed with opponents in soccer matches. It was even said that sometimes, officials and members of the opposing team demanded that he should be dropped from the team before they would agree to play a match with them. Other accounts that I heard described how the young Agyimah healed the afflicted with herbs and foretold the future of people in Half Assini. These accounts added that he was always at the beach in Half Assini speaking out loud to himself and he would never tell who he was talking with. The accounts would often conclude that his healing powers were derived from that unseen being that probably lived in the sea. Adjalou was therefore only adding to stories I had heard earlier about the founder of the community.

The founder's checkered schooling history was also one focus of the stories that circulated about him. People often said this pattern meant he had already been chosen by the goddess to be her agent. Schooling then was a distraction. For example, Aunty Id/aa. a woman whose stall in the market was close to my mother's and who is a follower of Agyimah, said to me at one time about the leader, "He did not want to go to 
school and when his parents forced him, he would mess up....speak rudely to the teachers and headmaster and always he would be punished, making school very unpleasant for him. But he never knew himself what he was doing. The goddess was instigating him to act that way."

Reflecting on these earlier stories and what Adjalou was telling me I was beginning to understand the sources of the followers' belief that their founder was special and an agent of the goddess. In fact these stories convinced me that the concept of charisma would be a good theoretical tool to capture the role of the leader in the origins of the community.

Typically, accounts of people who found religious movements in African communities contain episodes in which the supernatural go-ahead to begin their mission would be made clearly known to them and to the public. Often they would create religious communities after the episode. According to Adjalou, Agyimah's call to begin his mission came one day when he went to the beach again and underwent a mysterious experience. Adjalou described the momentous encounter with the goddess that eventually led to the founding of the worshipping community:

One day an event happened that changed his life forever. He went to the beach as usual to communicate with Mame Wata. This time he never came back. For one week he was missing. His family searched the whole of the village and the forest but could not find him. Just as the family gathered to think of the next step to take he emerged with a dry skin. He narrated to them his one week stay with Mame Wata under the sea. He described the mansion of Mame Wata, her different servants, his initiation to be her priest- to heal humans and teach them the right path to prosperity and inner peace, and his marriage ceremony to Mame Wata.

"So he was married to Mame Wata?" I asked, puzzled. "Yes," Adjalou replied and continued. "That is why he cannot marry even though he has grown. He must remain 
solely married to Mame Wata and can break the marriage by having sex with other woman. He said Mame Wata said any woman he has sex with will die." Adjalou ended his story with this account.

On another day when I met Osofo Azani, the leading priest of the community he repeated most of the themes from Adjalou's story and the bits and pieces I had gathered from other followers. But he also filled in the missing gaps in these accounts by telling me about how Agyimah invented a worshipping community after this momentous religious experience:

After that event he became a priest and he healed and protected people spiritually. As time went by, people heard of him from all over and they would come with all kinds of problems and he would heal them. Then they started to gather around him. People came from all over the area, so they built a shelter to accommodate them. And that was how this church began.

"But was it a Christian church from the beginning?" I asked, him wanting to find out how an encounter with an African goddess will result into a Christian community. "No," he said, and went on. "But in the beginning they organized it like a Christian church. They read the bible, sang praises and worshipped with drumming and dancing." "They worshipped who?" I wanted to be sure. "They worshiped Mame Wata who gave the powers to Agyimah," he replied. "Why did they organize it like as Christian church?," my quiz went on. "Because most of the people who were coming to him were already in Christian Churches," he replied.

It was now becoming clear to me that Agyimah wanted to establish the worship of the goddess and felt that he could do this more easily by placing this cult within the religion that his followers were already practicing. He was re-inventing an old tradition using Pentecostal Christianity as his organizational framework. This was unheard of at 
this time, but the belief that he was not acting all by himself was so strong, and the fact that he healed people made him so appealing, that people followed him anyway. Even though I was not aware of these events at the time they were happening because I was a child, now I am able, by drawing on my political science class at the University of Ghana as an undergrad, to reflect on the socio-political climate of the time. This was a time when the economy of Ghana was in total collapse. The country was plagued with hunger, drought, and bushfires and in the political arena coups and military take-overs were common. At the same time "development experts" and donor agencies agreed on the importance of macroeconomic policies such as Structural Adjustment programs for the development of sub-Saharan Africa. ${ }^{63}$ The Structural Adjustment Program ${ }^{64}$ (SAP), they felt, would bring poor nations such as Ghana back on track. But the structural adjustment packages led to loss of jobs in the formal sector. In Ghana at that time, most of the breadwinners of households were men and losing their jobs meant trouble.

The citizenry were worried about the situation and needed a way out. In African religious traditions, people seek spiritual symbols to help them solve material problems. This is because in their worldview, there is no separation between the physical and the spiritual. They are intertwined. They feel that the physical happenings reflect what has gone wrong in the spiritual realm. Agyimah, then, must have had what O'Brien would describe as a charismatic clientele--that is people seeking spiritual solutions to their

\footnotetext{
${ }^{63}$ Christine H. Gladwin, Structural Adjustment and African Women Farmers (University Press of Florida, 1991)1.

${ }^{64}$ The structural adjustment program. supported by the International Monetary Fund (IMF) and the World Bank. led to the economic collapse in Ghana and other African countries who adopted those reforms in the 1980 s. For more on SAP see Gladwin, Structural Adjustment and African Women Farmers (Gainesville: University Press of Florida, 1991) 2.
} 
problems-- following him. This may even have made him bolder in establishing the worship of a goddess within a Pentecostal church.

As I have said earlier, Half Assini is a matrilineal society and in the pre-colonial past women generally had much power. They were leaders and the originators of much that happened in the village. It is therefore significant that it was a goddess and not a god that inspired Agyimah to create this community. As I argued in Chapter Four, in African communities, religious beliefs are sometimes avenues through which people express feelings-desires or fears, or simply experiences-rooted in their socio-cultural lives. Given the characteristics assigned to her, Mame Wata embodies many pre-colonial ideas about women's power and their crucial role as the foundation of Nzema matrilineal community. The belief that Agyimah's source of powers was Mame Wata is one way for this community to express a connection between spiritual power and the power of women in material society. Emile Durkhiem says that the spiritual is often a peoples' expression of their social realities. This is the basis of my argument that Agyimah's initiative amounted to a restoration of something that belonged to the past-- belief in the power of women. His charisma enabled him to do this. Having discussed the role of Agyimah's charisma in the invention of the worship of Mame Wata in the Christ Deliverance church, I will go on in the next chapter to describe the community, what they believe and what they practice. 


\section{CHAPTER SIX}

\section{THE "CHILDREN OF MAME WATA:" THE WORSHIPPING COMMUNITY}

The Christ Deliverance healing church has a very big rectangular gated compound. Every structure on the compound is painted blue and white. These colors are symbolic. The white symbolizes purity, and on the days they are performing special rituals the priest and members dress in white. "Mame Wata is pure and her followers must be pure, too," a priest explained when I asked him about the symbolic meaning of the color white. The blue symbolizes the sea, which is believed to be Mame Wata's home.

In the middle of the compound is a shed with short concrete walls and a corrugated iron sheet roofs. This is where members worship. Upon entering this section, one sees two alters, one on the left, the other on the right on the eastern end of the room. On each alter is an opened bible. Drums, rattles and gourds are at the back of the altar. There are benches and plastic chairs for worshippers who want to sit down during worship, but there are just a few; during worship most people sit on the cement floor. Between the two alters and the seats is an open space where worshippers dance to the melodious music produced by the singing group during worship.

In the compound are other rooms. These are rectangular. Some of the rooms host sick people who are detained by the priests and priestesses so that they can go through sessions of healing or deliverance. Other rooms are the residences of the priest and some of the church leaders who reside in the compound. There is a gate that leads to the holy room at the back of the altars. The holy room has two chambers. Consultations with Mame Wata and rituals take place in the outer chamber. The priest described this room as 
a "special room" and I agreed with him, when upon entering, I felt the presence of spiritual power myself. It is a feeling I cannot describe adequately but one that grips you once you enter the room. The pictures of Mame Wata, Jesus, and Mary are hung on the wall of this room. There is also an altar in the corner of the room. On the alter is a big picture of Jesus, effigies of Mary, Mame Wata's incense, and a covered bucket of sea water, representing her home. A white cloth with a blue print of the cross covers the altar. Beneath the altar is a mat. A stool on the mat serves as the seat of the priest. This holy room is visited by the priest alone on ordinary days, but during their ritual and healing service believers also go there to consult with the priest, to pray for themselves and to seek Mame Wata's help. The inner chamber is said to belong to Mame Wata. Because I was too terrified to enter this room when the priest invited me, I am not in a position to describe it.

Behind the section used for worship in the compound is a heap of pure white sea sand. This is the most striking feature of the compound. On top of the sand are a cross and an opened bible. At the base of the heap of sand are white shells from the sea, both big and small, coins and cowries. Some of the shells are inserted partially into the sand whiles others sit atop it in the form of a decoration. There is also a well filled with sea water. Inscribed on the wall opposite the well are the words "Saint Agra" and "Krishna". Agra is considered to be one of the most powerful goddesses of the community and "Krishna" representing the Hindu god, is also a god of this community. Osofo Azani, the priest, explained that the sea water is used for healing and ritual purposes and that sometimes when a person is on the verge of dying, they place the person at the base of the heap of the sand. After incantations and consultations, some of the shells inserted in 
the sand are removed and put in water. The water is then poured on the patient. Members said that if it pleases God and Mame Wata, the patient will be healed. The members are permitted to go into the holy room to pray to God and Mame Wata to have their wishes granted. As I reflected on their explanations I wondered what the sea water and sand symbolized. As if the priest was reading my mind he said, "Mame Wata's presence is in the sand. The sand is not ordinary sea sand, but was fetched from the bottom of the sea, the very heart of where Mame Wata dwells."

\section{The Followers: Mame Wata's Children}

While the priest identified about eighty regular attendants of the church, he also agreed that it was not easy to determine the membership. "Some people come only once in a while. Others come only when they face problems. And when their problems have been solved they attend church for a while and then you do not see them again. Then there are these Christian pastors who come to us to get powers from Mame Wata so that they can perform miracles in their churches." he said, trying to explain the different categories of members. His reference to Christian pastors reminded me of an earlier episode in which a traditional priest by the name "Kwaku Bronsam" threatened to expose Christian pastors who had come to him for help, but had not paid their dues as members of his community. Kwaku Bronsam actually went to a Christian church in a town called Brekum to collect his god and the power he had apparently loaned to the leading pastor of that church in order to help him get and retain members. ${ }^{65}$

\footnotetext{
${ }^{65}$ Anastasia, Cudjoe. "Fetish Priest Exposes Pastor" People and Places, 10 August, 2008. 1
} 
Adding these categories noted above together, the priest of Christ Deliverance pegged the total membership at three hundred, including women, children and a few males. Most of the members I met were women between twenty-four and fifty years old. There was something distinct about the men. They are only a few and their ages range only between forty-five and fifty-five years. This is significant because in African religious thinking, growing up means one is getting nearer to the ancestors, so the urge to be sacred, to lead a good life, to be able to fit into the world of the ancestors when one departs, becomes stronger with age. This explains why men of that age go to the church. Most women go to the church with their children but without their husbands.

The female members are mostly petty traders, farmers, and fishmongers struggling to be successful in their business and depending on the goddess for spiritual aid in their daily struggles. The women are mostly Nzema and are either illiterate or semi- literate in English. But very well-educated people such as politicians, teachers, and civil servants also visit the priests from time to time when misfortune befalls them and they need spiritual help.

\section{Tenets}

We worship God; we do well and keep ourselves pure, we are also striving to go to heaven just that we use a different route. We worship God and the goddess, Mame Wata. We are not evil, we don't kill. There is black power and white power. The black power is the "juju" ${ }^{16}$ of people who kill, but we use white power; we save, heal and avert the effect of the black powers. ${ }^{67}$

\footnotetext{
${ }^{60}$ Juju is a type of charm prepared to harm others or protect a person.
} 
These are the words of Osofo Azani, the priest of the worshipping community, in response to my question about what the community believes and practice. Even though the Christ Deliverance church describes itself as a Pentecostal church it combines some external elements of Pentecostal Christianity with Nzema traditional religions. At the center of their ritual life is Mame Wata, the goddess. Contrary to other Pentecostal churches that view African deities as agents of Satan, the Christ Deliverance Church regards African deities as children of God and equivalent to angels in the Christian tradition. "Those are God's children that decided to come from heaven and live in this world. Mame Wata then is an angel and a daughter of God," Osofo Azani, the priest, said to me explaining how Nzema gods and goddesses are God's children. As an angel, Mame Wata intercedes on behalf of members of the community. She guides, heals and protects them in every activity that they participate in. Members talk a lot about the need for one to have faith in God and Mame Wata, God's child, in order to benefit from them. The members are also taught to do good all the time in order to get blessings from Mame Wata.

The community's major text is the Bible, but it prefers the Old Testament to the New Testament. One of their pastors explained that the Old Testament carries cultural themes which are analogous to the Nzema worldview and hence its usage as scripture.

Most members I spoke to said they had never seen Mame Wata in physical form. But many explained that she appears to members in dreams and visions. They also believe in her healing, protective and providential powers. So strong is the belief in the power of the Goddess that a member cannot complete a conversation with an outsider without mentioning this fact. A woman even said pastors from other churches came to 
their community seeking after some of this power: "Members of other churches sometimes see us as agents of the devil but their pastors come to us for powers. Again we do the right thing always."

\section{Ritual Life}

The central focus of the church's ritual life is healing. This healing tradition evolves around Mame Wata, who dispenses her healing ability through the priests of the community. In Nzema thinking, health means the totality of a person's well being--good physical health, prosperity, success, and long life. In a fast globalizing Nzema world replete with a myriad of challenges, Mame Wata professes to have answers to questions relating to members' physical, material and spiritual health. From my interviews I gathered that afflictions for which people consulted the priest range from barrenness, bad marriage, lack of good will, poverty, bad dreams, farms not yielding crops, and lack of intelligence.

In the community's healing practice ritual paraphernalia, such as white calico, eggs, dove, fowls, incense, candles, cologne, Florida water and white clay are used. These healing items are prescribed, depending on the magnitude of the problem the afflicted wants to resolve. Sacrifice is an important aspect of the healing process. When the appropriate sacrifice is performed a person is set free from an affliction and is free to go. If the problem is physical--such as a protracted or a mysterious illness-- the healing process can be physical. In that case herbs, leaves, barks and root are used as medicinal remedies. But health is never fully restored without some form of spiritual mending or fortification of an afflicted person; the priest uses a number of ritual processes in taking 
care of this aspect of healing. Only after spiritual healing is effected is a person considered fully healed. But healing also involves protecting individuals against attacks from evil forces. For example, the priest prepares concoctions for people who are being hunted by an evil spirit. The belief is that when the victim smears the concoction on his/her body the evil spirit will disappear from his or her life. According to the priest sometimes people experience misfortunes because the "sunsum," which is a spiritual element within a person responsible for the person's traits, may have left the body to wander in other parts of the spiritual universe. In such instances his healing involves using the powers of Mame Wata mystically to "pull" the sunsum back into the victim's body to put the person on track.

Even though they use the Christian word "pastors" in describing their roles, the priests resemble traditional African priests. Some of them are considered to be married to Mame Wata, in the same way priests and priestesses in African religions are considered to be married to the gods and goddesses. Others have human wives. Even then they consider Mame Wata to be their first wife and their sex lives are highly regimented. Mame Wata gives them a timetable according to which they have sex with their human wives. Noted for her lust and extreme jealousy, Mame Wata severely punishes any priest who ignores or goes against these rules. She is a first wife and no one dares to incur her displeasure. This practice is reminiscent of an African polygamous home in which the first wife has power over other wives and much of what the husband does.

Sundays. Wednesdays and Fridays are the days the community meets. Sundays are the days for church services. Wednesday is midweek service; and Friday is the prayer and ritual session. Both male and female members dress in white gowns during the ritual 
session. When entering Mame Wata's room on this day, members count their steps as a form of reverence for the goddess. Every four steps they make they stop, kneel, bow and pray before entering the room. Worship involves singing and drumming amidst clapping of hands. Offering is given according the day one was born. Sometimes special offerings are given.

It is my opinion that this church is a spiritual "pull house" pulling together the powerful spiritual figures in other religions. This is so because Krishna, the Hindu deity, is one of the gods of the community. Sometimes the community is referred to as "the Christ Healing Deliverance Church, Krishna." This reinforces my claim that the church as an "invented" African tradition. It shows also that in the process of inventing traditions in a globalizing context new symbols floating around can become a part of the new tradition that is supposed to link the inventors with their past. In an African context this is easy because in African traditional religions powerful gods and goddesses can be pulled together and worshipped so long as they continue to serve the needs of the people.

\section{The "Fete" Event}

Every year all worshippers of Mame Wata in the entirety of the Jomoro district and in Ivory Coast gather to celebrate a feast in honor of the goddess. This feast has been dubbed the "Fete." The Fete is a week-long bazaar packed with activities. The package is both spiritual and social.

The spiritual activities involve rituals designed to solve the spiritual needs of the believers. They include a cleansing exercise intended to deliver members from both bondage as well as the grips of the wicked. Members and the priest of Mame Wata can 
visit the seashore with specific required objects - Florida water, special perfumed water used by the members, Saint Michael perfume, talcum powder, strong scented soaps- for a ritual bath. Mame Wata, I was told, is a high society goddess "who likes all the good stuff. She loves good smells." The founder of the community, though male, dresses like a woman from head to toe in preparation for the rituals and leads the procession to the shores for the ritual bath. A local sponge made from a plant is used for bathing in this purification exercise. This ritual bath wards off all that is evil. Followers literally wash away all that has affected and afflicted them in the past year in order to start the New Year with a clean slate with fresh blessings from Mame Wata

The fete is also a gathering where the community socializes and the social needs of the people are met. The Saturday of the weeklong Fete is dedicated to social activities. All the believers converge at one place for thanksgiving and offering. The believers bring clothes, money, food and their tithes. On Sunday the items are distributed to those among them who need them.

There is nothing like common proselytizing in this church. Members are people who came to consult with the priest on a variety of issues and when their problems were solved they remain as faithful worshippers of the goddess. These members in turn bring in new members from circles of relatives friends and acquaintances.

In the next chapter, I will report narratives celebrating the fear of this powerful goddess, Mame Wata. I argue that these stories re-visit both the awe that is a common response to gods and goddesses. and patriarchal fears of the power of women. 


\section{CHAPTER SEVEN}

\section{THE FEAR OF MAME WATA- REVISITING THE MYSTERY OF THE FEMALE}

One of the main themes that emerged in the course of my field research was the fear, mystery, awe, respect or reverence surrounding the persona of Mame Wata. Most of the narratives told of the very frightening scenes or episodes that heralded her appearances to those who encountered her. People were even reluctant to talk to me about her without her permission, lest they unknowingly offend, and risk her wrath. Some narratives described how those who disrespected her by running away after evoking her presence went mad. Others told of her very demanding nature and having very frightening visions of her. We cannot tell whether these revelations really took place or not. We can, however, treat the narratives as reflections of peoples' ideas about Mame Wata. Drawing from these themes I will extend the argument I began in the previous chapter about the worship of this goddess representing a modern invention embodying the powers of females in pre-colonial Nzema society, a matrilineal group. In this chapter I intend to argue that fear of Mame Wata is reminiscent of the awe, fear, respect and mystery surrounding the female in pre colonial Nzema society. Traditional beliefs practices and institutions seldom die away completely--- they find expression in modern forms. One duty of us as scholars is to tease out from the modern forms the themes or ideas of the past that are being expressed. 


\section{The Fear of Mame Wata}

Not everybody in Half Assini worships Mame Wata but the beliefs surrounding her seem to influence most people, members of the Christ Deliverance Church and nonmembers alike. In seeking to know what people thought of the goddess, I did not restrict my questions to church members only. I also talked to others, especially those who lived on the shores and depended on the sea, Mame Wata's home, for their livelihood. ${ }^{68}$

In Half Assini the mention of Mame Wata's name sends shivers down one's spine. She is greatly feared. One theme that reflects this fear is her very frightful appearances. Osofo Azani, a priest, told of what happens when one invoked the presence of this goddess:

When one goes to call Mame Wata she will not come right away. Before she comes there will appear a number of very frightening things first, a dragon, then a lion, then a double-headed snake, and all these are her. Those that cannot stand her parade of these very frightening forms would run.

"It is when they run that she punishes them with madness. She sees running away as disrespect and will make a person mad as a punishment to deter others. So one must be prepared to stand up to all those frightening forms if one wants to see her," he concluded, describing the consequences of running away from the goddess.

The narratives of the fishermen of Half Assini who fish in the sea and live along the coast were also full of these frightening details. A young fisherman I spoke to reiterated the theme of fear in Azani's account when he told me of what he knows about

\footnotetext{
${ }^{68}$ Though most of the people I interviewed at the beach are presently not full members of the Christ Deliverance church, some of them were at once members. Many visit the church when they have problems they need, Mame Wata's help.
} 
the goddess. "Mame Wata has given a phone number to people," he said, after narrating a story about a friend's encounter with the goddess. He continued:

The phone number is 888 and when you call the number Mame Wata will respond to the call from her home under the sea. She will promise you anything you ask for but first you must be prepared to meet with her at night and alone at the beach. She will instruct you on how to behave, the time to meet her and the particular spot on the beach when you dial the number... if you refuse to meet her you will begin to experience hallucinations. And should you decide to go; a series of terrifying things will appear and disappear before she comes. You just have to stand there; if you run, you are a mad person.

When I asked whether he had made any attempt to call Mame Wata, he replied emphatically "NO." "This goddess is so fearful -you need to possess the heart of a lion to be able to stand in her presence. For me I don't have that kind of heart .....and I don't want to be mad," he explained. Another fisherman said Mame Wata was the giver of fish. She places fish in the sea. He said he feared the goddess because if she becomes angry or offended by the people, she could stop the flow of fish and that could mean the end of the source of his livelihood. Kwaku Manu, a fishermen I met at the beach, described how they prayed, calling on both God and Mame Wata for help. "This is because she is in the sea and can help us get fish or not," he explained. He affirmed that if fishermen offer her a sacrifice of talcum powder perfume, etc, and smear some on their boat, she smells it and reveals herself through a sign, such as making fish jump noisily from the sea. When the fishermen cast their net at where the noise came from, they got a bumper catch. "But you don't annoy her because she will deal with you. You must fear that goddess," he cautioned me.

Kojo Bentum, a 46 year old neighbor and a friend of my uncle, narrated a story of a friend who wanted to acquire mystical powers that would enable him to perform forms 
of magic. His account also contained fearsome details of what this young man had to endure:

He went to call Mame Wata at the beach in the night. He said that after a series of fearful things appeared to him, Mame Wata revealed herself and directed him to go the bush and to put his hand into the mouth of a lion. He said he went and did as he was told. When he pulled his hand from the lion's mouth a ring was fitted on his finger. From that time he acquired magical powers. That is the power he uses for his magical performance. If he had run away after those fearsome things he would have been mad.

This narrative reveals an important theme about women in Nzemaland and this is the fact that just like any mother, when Mame Wata promises, she delivers. But the faithful must do their part by obeying her rules and regulations. One who disobeys Mame Wata would be punished severely just as a mother would punish a recalcitrant child. On the other hand a child that obeyed the mother will share in her privileges, just as Mame Wata generously delegates some of her powers to followers who were obedient to her. Furthermore, even though the Nzemas look on mothers as loving, warm, and nurturing, because of their central roles as the transmitters of societal values to subsequent generations and also as the disciplinarians in homes, the Nzema mother can also be feared by her children. I suggest that the imageries of fear, fright and mystery expressed in the Mame Wata narratives, though exaggerated, are reminiscent of these sentiments.

Some narratives described the mysterious forms the goddess took when appearing in human society. This was also a source of the fear and the awe people had for her. According to some of these narratives, the goddess mysteriously turns herself into a woman when she comes to town. On a Monday in the Half Assini market, a woman told me of a recent incident that occurred in Half Assini featuring one such mysterious 
appearance of the goddess. This woman, the wife of a proprietor of a preparatory school

in Half Assini, narrated this incident to me first hand:

I went to the market and a small girl said she will go with me. So I asked her "go with me to where?" "I will go with you to wherever you are going" she answered. "But what about your parents?" I asked, "I don't have any," she answered. "They are dead" A woman sitting by confirmed that in actual fact the little girl was an orphan. So I took the girl to the police station and told them I was taking her with me to Half Assini. I gave my contact information to the police, so that they can contact me in case someone comes looking for the girl. When I brought her home she was good and did things perfectly. But one day some charismatic church people came to pray in our school during an all night session and we went with the girl. Just there and then the girl started acting strangely. She was shouting and insulting any one who would touch her. Later, she vanished from the prayer grounds. During the search for her we found her on beach. We were alarmed. We took her home and started praying for her. That was when she turned into half fish, half human. When we continued the prayers she confessed that she was sent by Mame Wata to come and destroy the school, us and our family. Quickly we sent her back to the police station in the town where we picked her. You see, my sister, Mame Wata is so crafty that she comes in different forms and packages that you least expect, and by the time you are aware she would have totally destroyed all that you have. I guess Mame Wata was upset with my family because our school is not far from the sea and we invite powerful Pentecostal pastors to preach and pray with our students from time to time.

Another woman, the wife of a fisherman, said she had heard Mame Wata had children in Half Assini. But she added, "These children of hers... they are human, but they can turn into snakes anytime they want to." People fear snakes greatly in Half Assini, not only because of their venomous bites, but also because they believe that evil spirits commonly use snakes as their agents. The association of Mame Wata with snakes is an important source of the fear people have for her.

Another theme related to the fear of Mame Wata has to do with how forcefully she could seize people, marry them, and procreate with them. On a Saturday at the beach in Half Assini a woman told me about how Mame Wata would sometimes come to town, marry someone forcefully and give birth with them. According to the woman only the 
person who Mame Wata marries and the children see her visibly. The woman also said, once a person marries Mame Wata he/she is tied to her alone. "She will make you mad if you go after another man or woman," the woman concluded. Similar accounts described how Mame Wata could take the form of either a woman or a man to marry some one of the opposite sex.

What struck me about these accounts was not only how a goddess could marry a woman and procreate, but also how a woman could take the lead in making a proposal to a man or seize a man and impose her will on him. In contemporary Nzema society men normally approached women and proposed marriage or friendship, not the other way. People consider it a sign of her boldness, strong influence, strong will or her tendency to be control a man if a woman approached a man and proposed friendship or marriage. All of these attributes point to a woman's power. The theme underlying these forceful marriage narratives then was the power of Mame Wata and her arbitrary use of this power, because of which people fear her greatly.

Mame Wata's quickness to punish and her mercilessness in dealing with those who annoyed her is another source of the fear people had for her. Enyaku, a fisherman, said to me at one time, "no one can mess with Mame Wata; if you do she will destroy you completely." He described an incident that happened a year ago, that terrified him so much:

Some fishermen went to sea and their boat capsized. There were twelve of them; only four survived. What led to the capsizing was that one of the fishermen had insulted Mame Wata during a Christian "all night" session. The man had said he was a child of God and Mame Wata is Satan and an agent of the devil. Mame Wata then possessed some one at the beach and used that person to tell the man to apologize to her otherwise she will show him where the power lies. The man and his two children and other members of the family then went to beat up the person possessed by Mame Wata. The next day they went to sea, and that was 
when their boat capsized. The man, his two sons, and family as well as friends on the boat all died.

Enyaku, whose home is on the shores of Half Assini, also said he was terrified by the fact that Mame Wata lives close by and sees as well as hears whatever, goes around,. "It would be foolish for a person to speak ill about such a powerful goddess when we all know she can affect us for good or bad and that her punishment is unbearable," he concluded.

A fisherman said the reason he feared Mame Wata was that she was crafty and was a liar. "If you give her attention she will always be up to something," he explained adding that he and his group of fishermen prayed only to God and do not care about Mame Wata.

There is so much fear surrounding the name Mame Wata that some people were reluctant to talk to me at all about her or allow their children and wives or husbands to divulge information about her. When I would ask the fishermen especially about the goddess, they would simply respond "she is the queen of the sea. She gives those fish." They will not go any further. Presumably this was because we were standing right by the sea, where Mame Wata lives. They were convinced she sees and hears all what we would be talking about and that if they said anything annoying to her something bad would happen to them at sea. Their boat could capsize or they would not get fish.

Awe, fear, respect and a sense of mystery are related sentiments. They are also related to power, for it is entities who have power that elicit these sentiments from less powerful others. While these sentiments are common responses to gods and goddesses, it would seem to me that in Half Assini they are associated with goddesses more than they 
are with gods. Aside from Mame Wata, other goddesses elicit such sentiments because of the spheres of life they control, their power, and their ruthlessness in dealing with those that violate their rules. For example, Egyake Bule, the water goddess who oversees all activities in Half Assini is a very strict disciplinarian noted for mercilessly dealing with those that violate her rules. She inflicts incurable illnesses on offenders. Bula Adwoba, the goddess that controls trade and oversees activities in the main Half Assini Market takes the lives of an offender unless the offender pays a big ransom. Those that offend Gbgogbo, the goddess that guards the Abbey lagoon, will never reach their destination if they attempted to cross the lagoon. The boat would capsize. These goddesses are greatly feared in Half Assini, and like Mame Wata narratives about them are replete with their fearsome appearances and episodes. In contrast women in modern Nzema societies such as Half Assini live on the margins occupying very low positions. They are not very much feared or even respected because they do not control much power and influence. In line with my earlier suggestion that African goddesses also embody societal ideas about women I argue that these goddesses are signs of the Nzema past when women wielded so much power and influence that they were highly respected, even feared.

From the stories reported in this chapter we see how much Mame Wata is feared on account of the belief in her power. The imageries used to describe her- snakes, tiger, hyena, dragon, lion, snake with seven heads, fire, or a human with seven heads-, the fact that people cannot stand her and yet they become mad when they ran way, the fact that she can forcefully marry anyone of her choice, and the fact that she will punish those that annoy her severely are all indications of her power which makes people fear her. This fear. I argue, is reminiscent of the fear awe and respect and mystery that surrounded the 
female in the past. For this reason I argue that through Mame Wata notions of female power and mystery are still being celebrated in modern times. This is why I maintain that the goddess embodies ideas about female power--ideas that lost much influence because of colonialism-- and are being reclaimed in the present times. 


\section{CHAPTER EIGHT \\ EMPOWERING WOMEN}

In this chapter, I will report narratives of the female worshippers of the Christ Deliverance Church describing the various ways in which Mame Wata empowers them. The talked about how Mame Wata, the powerful goddess, is a mother who looks after them, gives them children, heals them and their children physically when they are ill, and supports their business ventures, ensuring that wealth and abundance flow into their homes. My point in reporting these stories is to show how these women, who are already taking advantage of all the empowering activities taking shape in modern Half Assini, are also deriving additional strength from the beliefs that celebrate the powers of Mame Wata as they continue to perform their roles as women. In the face of the challenges they face daily, the belief in the goddess empowers them and gives them the strength to go on as women.

\section{Mame Wata the Mother and Healer}

In Half Assini, a mother is a healer. This is both because health is defined in totalistic terms as the overall wellbeing of a person and not only the well-being of the material body and because mothers are entrusted with ensuring the overall well-being of the community. Good health means having good food to eat all the time and nurturing one's body, having good clothes to wear, having a peace of mind[azomdwele], being in tune with the spirit beings and enjoying material abundance through success in one's activities. As cultivators of food, preparers of meals and feeders in homes, mothers ensure the good physical health of children and husbands. Through their petty trading 
activities, they ensure that their families are clothed and have the other basic material necessities of life in the home. When a child is ill in a home, the mother is the first to notice it, or the person to whom the child would first report the illness. Primary health care provision is a mother's responsibility. She would perform the initial diagnosis or consult other mothers for help and notify the ritual specialist or the modern doctor later. When a child gets into trouble outside of the home, the mother is the first person from whom that child seeks consolation and advice. Professionally most healers in Half Assini are women and mothers.

In addition, when supernatural forces of evil threaten the security of the home, mothers lead in domestic prayers, and take the initiative to solicit the services of ritual specialists who keep these forces at bay. In the indigenous thinking of Half Assini all, these activities constitute healing. A mother then essentially is a healer.

In the Christ Deliverance Church worshipping community, Mame Wata is often referred to as "our mother." In fact, outsiders often refer to the members as "the children of Mame Wata". Moreover, while responding to the questions I would ask them during my interviews members would often say, "She is our mother," before going on to recount the various ways in which she dispensed her duties as a mother. In most of these accounts, followers would describe her motherliness in terms of her healing activities.

Many of the followers said what motivated them to join the community was the fact that they would benefit from the healing powers of the goddess. Most of them said they joined the community after they or a relative had benefited from the "mother's" healing at one point. Ajuamang, a trader, told of how her son nearly became mad and 
was healed only after she brought him to the "mother." "Since he came to Mame Wata he

has been healed and is fine," she said before starting into the story:

He was always sick and got into trouble all the time with the authorities of the school. Finally, he nearly got mad. He behaved like an abnormal person and when we went to consult a spiritualist, we were told that a spirit was worrying him. We moved from church to church seeking help. I said that if we did not seek help. he would die. Someone said we should bring him to this centre-Christ Deliverance Church. And Mame Wata healed him from all that was troubling him. That is the story of how I came here. He would have been roaming about mad or probably dead by now if Mame Wata had not healed him. So Mame Wata holds our lives here. She is a mother and knows what it is to have a son go mad and that's why she will do anything to heal any sick person. When you are here you have nothing to worry about because she is there [she would protect you].

"People make fun of us for attending Mame Wata's, but for me this is where I belong...because I know there is no way any illness will kill me. Not when mother is there," Auntie Akos, a member who sells vegetables in the Half Assini Market, said to me when I inquired how she became a member of the church. "If only you pray and have faith in God and Mame Wata, she will heal you always and give you favor as well as protection," she explained exuding a great deal of confidence in the goddess's healing abilities. She narrated her story:

I was sick for about 3 years and had to go from hospital to hospital and to healing centers looking for help. Finally when I came to this church she healed and saved me within a very short time. You see, all depends on your faith. If you have faith in her she will provide you with everything. For us who are here Mame Wata is our savior. So we will worship her all the time.

A middle-aged member by the name of Homa told me of her own experience:

I was a strong, well and fit woman until I fell sick one day. When I went to the hospital, they said it was malaria and they gave me medicine. However, that was when everything started. The malaria will not stop. That was when we knew it was a spiritual illness. My family took me from one hospital to another but nothing good came from their moves. Then I became paralyzed. Oh, my legs... they will not move again. Then I began to think-who will take care of my children if I can't do anything. What will they eat? What will they wear? Then 
they took me to a prayer camp and I stayed there for three months, but still, it did not help me. Then someone told us of Christ Deliverance Church, so we decided to come and try. When I came to this center, after the consultation and divination, the priest started working on me. He said if I believe in Mame Wata and God, I would be healed. In no time, I started getting well. First, I could move my legs and body. Then I could lift myself without help. One day after being there for two weeks I started walking again.... though not so well but I could stand on my feet. That was when I believed in the delivering and healing power of Mame Wata. Mame Wata is my healer.

She went on to describe how she depended on the goddess daily,

Anytime I am not feeling well I just pray to her, come to church and smear myself with some of the sea water in the well and take some home. I know because Mame Wata is in the water she will heal me so I get well. Eii! If it was not for her where would I be now? I am here and do what I do because she is there for me. She is the one that gives me the strength to go on

On a Sunday after worship, I asked Mansa, a fifty-year-old woman about what Mame Wata does for her after she had explained to me how many members like the church because of what the goddess does for them. Staring me in the face, she asked quietly but in a firm tone "Would you repeat that question?" She wanted to be sure she had heard me correctly. I repeated the question. "Every one goes to one church or the other because of faith," She started, and continued:

I have been a member of this church for more than 15 years now. In addition, you know why? Mame Wata healed me from a bleeding problem. It first it started as my usual menstrual cycle but it went on and on. I went to the hospital and was admitted. However, the different medication the doctors gave me will not stop the bleeding. It was on and off. Even my came to take me to the hospital but at the hospital she could not stand how the blood was flowing so she collapsed. That time I was not a member but when I left the hospital, I came straight here. The priest did some divination and talked to Mame, then he used herbs on the blood flow and that was it. I have dedicated my life solely to worshipping "mother" ever since. You see my daughter you go to where you have faith that you will have protection to go on. My faith is in Mame Wada's power because she heals me, protects me and provides my needs and that is why I am here. Because of her, we get by everyday. In addition, for my disease like that ----she is also a woman so she understood what I was going through and knew exactly what to do to solve it. 
When I asked a 46 year old woman to tell me about the good things about the church she asked me a question in return, "Oh so what church do you attend yourself?". "Well, I am a Christian but with no particular Church," I managed to explain. "You people have forsaken the powers our ancestors left for us. But they still work," she responded and continued; "The gods still heal and protect people. At least I know Mame Wata does that because she has always protected me." She went on to link the benefits of the goddess's healing to the rising cost of health care:

If it was not for her, how would we manage? How would we do all the things we do; feed our homes, buy dresses for everybody, look after our husbands and pay for hospital visits on top of all. When Mame heals you, it is free. The mother does not charge anything. How could we go on without her?

In all of these narratives the women linked the benefits of Mame Wata's healing to their roles and lives as women. For them, the ability to be healthy and to go about their daily functions as women was empowering and Mame Wata, the goddess, grants them this benefit.

\section{"If you want a child she will give you a child"}

In Half Assini, children are not only a woman's most precious possessions; they are crucial sources of power for her. First, motherhood is considered to represent the fulfillment of a woman's full potential, for to be a woman is to be fertile and to be a mother. In fact, a woman who has a child is often referred to by her child's name. She is called "the mother of $x$ " [her child's name] in addition to her own name. This is a way of making publicly known the fact that she is a mother and a real woman. Children ensure 
the continuity of the society, and motherhood represents a woman's contribution to the immortality of the society. Mothers are therefore highly respected in the society.

Motherhood is beneficial to a woman in practical ways too. A mother is assured of help provided by her children, who would run errands for her and help her in her chores. When she is old and no longer strong enough to function; a mother would still have her children to take care of her. In such a matrilineal society, it is the property that the child inherits from a maternal uncle that he or she would use to look after the mother. A woman without a child is denied such benefits. Motherhood also has a spiritual meaning attached to it, for it is through childbirth that ancestors are able to return to live in and contribute to society. Motherhood also gives women the right and power to wield influence over their sons' wives. A mother can decide who her son should marry and when she is not happy with his choice she can ask her to leave. In fact, in Half Assini people have pity on a woman without a child. Bareness is considered one of the worst illnesses a woman can have. It takes away her respect, influence and power in society. Women will do all they can to solve the problem of bareness. Children are equated with power in Half Assini and because of her role as provider of children; Mame Wata is viewed by the women as a crucial source of empowerment.

A male member told me of his mother's ordeal with childbirth problems and how

Mame Wata helped her to solve it by giving him to her as a child:

She was married for thirteen years and still had no child. She tried and tried but it was not coming. Then someone said to her, 'why won't you go to Mame Wata? She will give you a child. Then she went and told the priest everything. The priest asked her to pray with him and to tell Mame all her problems and to make a promise to the mother that she will give her something if she granted her wishes. Two months after this she was pregnant with me... and after I was born, my mother made sure that we remained with Mame Wata. 
Another member, a twenty-nine year old woman called Araba Grace, told me of

how she was motivated by Mame Wata's help in giving her a child to become a member:

Three ex -husbands divorced me because of my inability to bear them children. I used to feel worthless. I would hide in my room all day and talk to no one. When I would come out and find people talking I would be thinking 'oh they are talking about my childlessness'. No body respected me. Some people called me a man [a way of insulting a barren woman] In fact; I was frustrated at the time I decided to try my luck at Christ Deliverance Church. I wanted to see if Mame Wata would help me. When I came, I told the priest everything about what I wanted and myself. The priest consulted Mame Wata, did some rituals, and said it would be well with me and that my wish had already been granted. I did not believe. That time I would have sex with a new boyfriend I had. We would meet occasionally for sex just for the fun of it. Then, one day I started experiencing changes and feeling sick. I went to the hospital and was told I was three months pregnant. Eei [expression of surprise] I kept it to myself until my stomach was showing. It became bigger and I gave birth to twins-a boy and a girl. How can I ever leave this church or the worship of Mame Wata? She helped me put my enemies to shame by giving me children. Now I have four children. And I feel good about it. Everybody now knows that I am a real woman.

A man described the miraculous pregnancy and childbirth of his wife stressing the role of Mame Wata in this miracle:

My wife and I have been married for some time now. At one time, my wife got pregnant. Her pregnancy was diagnosed as ectopic and one of her fallopian tube was cut. The next time she got pregnant, it was another ectopic, so the other tube too was cut. Therefore, it was medically impossible for her to have a child. However, my wife still wanted to get pregnant so that somebody too would call her mother. That is when she started going to the healing service and sometimes the Sunday services. She went for sometime, I cannot tell you how long but that was how the pregnancy came. She just became pregnant. And she gave birth through caesarian operation. Mame Wata is very powerful. I will not know how my wife and I would have had a child. You can image how useless she would have felt without our child.

Other accounts described miraculous childbirths of other members, some of whom. under normal circumstances should not have given birth because they were too old. All these accounts attributed the miracles to Mame Wata's intervention in the lives of the tellers. The point of reporting these narratives is to show how some women felt the 
ability to have children, a crucial source of female power in Half Assini, was a result of the goddess's powers and her intervention in their lives.

\section{Success in Business}

Another of the areas of life in which women are reclaiming their lost ground is trading. Many women in Half Assini are taking advantage of the credit schemes and other programs being initiated by the NGOs and women's organizations in Half Assini and are initiating small-scale business activities. Some female members of the Christ Deliverance Church said Mame Wata's help in their business ventures was crucial to their success. Mame Wata herself is viewed as a businessperson. Through her [or the seas], foreign goods found their ways into Ghana. This is why she is considered to be wealthy. It is also said that she possesses the secrets needed to succeed in business and transmits these to her obedient followers. Many women described how the goddess transmitted some of these secrets to them, leading to success in their business ventures. This story stood out among the many that followers narrated. Akosua, a petty trader narrated it:

First, when I sell things like that no one buys, I will wait and wait-no one will buy. Then I started coming to the church and started praying. Then one night I had this dream. A woman appeared and said I should relocate my stall and stop selling some items. Therefore, I did that. Nowadays I will go to the market and even on the days that the market is bad for other people, I will have many buyers. That is how things started improving. It was Mame Wata who came in the dream and she makes people come to buy. She protects my money too so I do not lose my profit.

Similar narratives contained details about how Mame Wata miraculously intervened in the affairs of women or their husbands leading to them obtaining loans they did not expect to be given, visions of Mame Wata that revealed new areas of lucrative 
business, and ritual paraphernalia obtained from the goddess through the pastor that protected investments of profits.

It was not only through these direct benefits that Mame Wata empowered these female worshippers. She was also a source of inspiration for some of them. Some women said she provided an example for them to follow. A prophetess of the community said to me at one time:

Women never forget to do things right just as Mame Wata. One thing we understand well in this church is that as women we must show how responsible we are. Mame Wata wants us to be good examples in society. She wants us to look up to her so that our children too can look up to us. And from her we learn that we do not have to be low in anything we do. We must be high up there just like she is. We must learn from her ways.

"In what ways?" I inquired, seeking further elaboration. That was when another member explained further, "This is it. Like Mame, like this [for example] she is a trader... And in her trading she works hard, is shrewd and goes after her profit wherever she can find it. And she does so, so that she can get things for us her children. That's how we too should be as women." On another day, a younger woman elaborated on this idea further, adding a different twist to the theme:

Mame is not afraid anything in this world. She goes anywhere she wants to and does anything she wants to do. If she must be ruthless, she is. She does not mind what anyone says or thinks. In addition, she likes the good things in this life. She likes to show off her good things and beauty too without being shy. She even shows her jealousy openly. In these days, that is how you must be like a woman if you must go places. If you are not like Mame in many ways - you will not get anywhere in life. In the church we do not only benefit from her powers, some of us ... we want to be like her.

These views were more prevalent among the younger female worshippers of the community. The reference being made here is to Mame Wata as the epitome of the notion of the liberated female, an idea catching up fast with the younger generation of Half 
Assini women. Mame Wata is very self - indulgent, given to a life of luxury, even openly sexual sometimes. She is independent and assertive, would possess who she wants to at will and harasses her desired followers through dream appearances until they succumb to her will. The ideal of the assertive, freethinking, open-minded, highly ambitious, independent female is replacing the notion of the female as a passive, submissive and a humble person who must always concede to the male. Clearly, some females see this changing image of the female in a very modern Ghana, which the goddess exhibits, as a model to follow and they feel they can draw strength from it as they contest prevailing notions about their place in the various spheres of social life.

Some of the roles that women played in the Christ Deliverance Church community itself reflect the power of Mame Wata that they share in. Aside from the head pastor and the assistant who are men, women control every aspect of life in the community. For instance the treasurer is a middle-aged woman called Mame Ablema. The members of the council of elders are all women and they all have ritual power and the ability to communicate with the goddess. Almost all the women elders I know are healers in the larger Half Assini society.

Even the women who are lay members do not view themselves as having less power or being subject to the authority of the male pastors as such. For them the male pastors are only representatives or agents of Mame Wata. During ritual performances, they assume the persona of the goddess, dressing, speaking and acting like women. They are pastors only because the goddess chose them. In many other Mame Wata churches, women lead. They are the pastors. Furthermore, in Half Assini as in many African cultures. people do not always construe female power in terms of women taking over 
domains previously occupied by men. Men and women are viewed as having separate but complementary roles. A woman's power lies more in her ability to function in a domain defined as hers - as a mother, a sister, an aunt, a trader, a nurturer or a healer. Power, it is said, is not always shown through what a person does - such as leading. Power can be demonstrated by a person through the withholding of his or her functions. Thus, if women stopped birthing, cooking, nurturing and healing, society would come to a standstill. Herein lays a potential demonstration of their power, that is, in not doing. For these reasons lay followers did not seem concerned that their leaders were males. At least I did not get this sense from our conversations. They were more concerned about roles they performed as women in the larger society, roles, which, if they stopped playing will result in chaos in society. They felt the goddess empowered them to perform these roles. 


\section{CONCLUSION}

In concluding this study I tie together the seams of the argument that run through the chapters. Drawing on participant observation and interviews, the study sought to investigate the origins of the Christ Deliverance Church, a Pentecostal church in Half Assini that worships an African goddess, and to interpret the religious experiences of the predominantly female following. The study traced the origins of the community to the Charisma of the founder, Agyimah, an agent of Mame Wata, the African goddess. Agyimah was inspired by an experience of the goddess to create a religious community. Looking for an institutional framework within which to establish the worship of this goddess Agyimah adopted Pentecostalism. Consequently, the community practices an eclectic mix of Christianity and African traditional religions, which I argue is a product of an invention.

The goddess, Mame Wata herself, who Agyimah adopts as the focus of worship, the study identified, is the product of a post colonial invention embodying Nzema ideas about the power of females-her ability to heal, her nurturing nature, the mystery surrounding her, the awe and sometimes fear of her power, that this community of female worshippers celebrate. Through the worship of this goddess then the female worshippers are drawing strength from indigenous ideas about the power of women in dealing with challenges that confront them today. In other words the goddess empowers them. They rely on her to heal them when they are physically ill so that they can go on with their lives. They rely on her for children, a very important source of power and they rely on the goddess's knowledge and skills as traders to succeed in their trade activities... 
Within the community itself, the women share in the power of the goddess by occupying very important positions. Even though they are not leaders, they sit on the council of elders; some of them are healers .Others control the community's finances. In other Mame Wata churches, women control all aspects of the community's life.

The study suggests that this development is not happening in a vacuum. It is reinforced by happenings in the socio-economic and political spheres of life in a very thoroughly globalizing Ghana. The changes globalization has introduced into Ghana are creating socio-economic challenges and women, who are very much marginalized are suffering greatly. However, globalization has also led to the introduction of western gender ideologies stressing the need for women to be empowered, into Ghana. NGOs are at the forefront of this move actively rallying women and facilitating their access to avenues of empowerment. It is in the context of these happenings that we must place the appeal of Mame Wata to these women. She is exactly the symbol of strength and hope the women in the study feel they need to take advantage of the empowerment of women campaign being championed by the NGOS. Moreover, relying on her, these women are able to meet their traditional challenges and the new problems globalization has introduced. The study suggests that we must not look at Mame Wata only as a Goddess but also as a repository of ideas about women in African societies. From these ideas her followers learn valuable lessons as they go through very troubling times. In other words, one of the major contributions of this study is the introduction of gender as a concept crucial to the interpretation of Mame Wata, the African water goddess. 


\section{BIBLIOGRAPHY}

Akyeampong. Emmanuel, and Pashington Obeng, "Spirituality, Gender and Power in Asante History." In The International Journal of African Historical Studies Vol 28 No. 3. (1995): 481-508.

Achebe,Nwando, Farmers, Traders, Warriors, and Kings: Female Power and Authority in Northern Igboland 1900-1960. Portsmouth. NH: Heineman, 2005.

Agbeti. J.Kofi. West Africa Church History: Christian Missions and Church Foundations 1+82-1919. Vol. 1 Leiden: E.J. 1986, 163-166.

Assimeng. Max. Religion and Social Change in West Africa. Accra: Ghana University Press, 1989.

Bastian. L. Misty. "Married in the Water: Spirit Kin and Other Aftlictions of Modernity in Southeastern Nigeria," in Journal of Religion in Africa, Vol 27,fasc.2 (May 1997): 116-134.

Bendix, Reinhard. Max Weber: An Intellectual Portrait. New York: Doubleday and Company Inc, 1962, 299.

Brettell. B. Caroline, and Carolyn F. Sergeant. Gender in Cross C'ultural Perspective. New Jersey: Prentice Hall, 2001.

Code. Lorraine. What Can She Know: Feminist Theory and the Construction of Knowledge. New York: Cornell University Press, 1991.

Comaroff, Jean and John Comaroff. ."Christianity and (olonialism in South Arica." American Ethnologist Vol. 13. No. 1 (Feb. 1986):1-22.

Clifford, Jack. The Predicament of Culture: Twentieth-Century Ethnography. Literature, and Art. Cambridge: Harvard University Press, 1988.

Cannadinc. David. "The Context. Performance and Meaning of Ritual: The British Monarchy and the Invention of Tradition 1820-1977." In The Invention of Tradition, Hobsbawm. E. and Ranger, T. (eds.) Great Britain: Cambridge University Press, 1983. 101-164.

Debrunner, Hans Werner. A History of Christianity in Ghana. Accra: Waterville Pub House. 1967.

Drewal. John Henry. "Mermaids. Mirrors. and Snake Charmers: Igbo Mame Wata Shrines." In African Arts. Vol 21. No.2. Feb., (1988) 38-96. 
-Performing the Other: Mami Wata Worship in Africa." In Journal of

Performance Studies TDR (1988-). Vol. 32, No. 2 (Summer, 1988), 160-185.

Eni. Emmanuel. Delivered firom the Powers of Darkness (Ibadan: Scripture Union. 1988).

Elom. Dovlo. "New Religious Movement in Ghana," In Journal of Africa Through Ghanaian Lenses. Vol. 5. No. 3 (1999), 183-190.

Frank, Barbara. "Permitted and Prohibited Wealth: Commodity-Possessing Spirits, Economic Morals, and the Goddess Mame Wata in West Africa.” In Ethnology Vol 34, No. 4.(Autumn. 1995). 331-346.

Geertz. Clifford. The Interpreation of Cultures. San Francisco:, HarperCollins Publishers. 1973.

Goody. Jack. 'Anomic in Ashanti.' In Afirica. 27 (1957), 356-63.

Gladwin. H. Christina. Structural Adjustment and African Women Farmers; Gainesville: University Press of Florida. 1991.

Grottanelli L.Vinigi. "Gods and Morality in Nzema Polytheism," In Ethnology Vol. 8, No. 4. (Oct, 1969), 370-405.

Hobsbawm. E. And Ranger, T. (eds.). The Invention of Tradition. Great Britain: Cambridge University Press. 1983.

Hackett. Rosalind I. J, “Mermaids and End-Time Jezebels: New Tales from Old Calabar." In UCLA. Unpublished paper presented at UCLA.

Johnstone. L. Ronald. Religion in Society: A Sociology of Religion. London: Prentice Hall, 2004.

Meyer Birget. "Popular Ghanaian Cinema and African Heritage," in . Africa Today Vol 46. 1999. 92-114.

"Visions of Blood. Sex. Money. Fantasy Spaces in Popular Ghanaian Cinema." Visual Anthropology, January 2003: 46-54.

"Make a Complete Break with the Past: Memory and Post-Colonial Modernity in Ghanaian Pentecostalist Discourse." In Joumal of Religion in Afirica. Vol 28, Fasc.3.(Aug,1998), 316-349.

"Commodities and the Power of Prayer: Pentecostalist Attitudes Towards "Consumption in Contemporary Ghana," Birgit Meyer and Peter Geschiere. Eds. Globalization and Identity: Dialectics of Flow and ('lostre. Oxford: Blackwell Publishing. 1999, 151-176. 
Meyer. Birgit and Peter Geschiere. Globalization and Identity: Dialectics of Flow and ('losure. Oxford: Blackwell Publishing. 1999.

Murphy, M. Joseph and Sanford, Mei-Mei. Osun Across the Waters: A Yoruba Goddess in Africa and the Americas. Bloomington: Indiana University Press. 2001.

O'Brien Cruise Donal B., "Charisma comes to town: Mouride urbanization 1945-1986", Donal B. Cruise O'Brien and Christian Coulon (ed.), Charisma and brotherhood in African Islam. Oxford: Clarendon Press, 1988, 135-155.

Oyewumi. Oyeronke. The Invention of Women: Making Sense of Western Gender Discourse. Minnesota: University of Minnesota Press, 1997.

Owusu-Ansah, David. "Growing up in Early Twentieth-Century Asante" In The Journal of African History Vol. 43, No. 3 (2002): 515-516.

Opoku Asare Kofi, West African Traditional Religion. Singapore :FEP International. 1978.

Olupona, Jacob, ed. African Spirituality: Forms, Meanings, and Expressions. New York: Crossroad Press, 2000.

Otto, Rudolf and Harvey, John W. The Idea of the Holy, London: Oxford University Press, 1958.

Sered, Starr Susan. Priestess. Mother, Sacred Sister: Religions Dominated by Women, New York: Oxford University Press. 1994.

Trevor-Roper. H. "The Invention of Tradition: The Highland Tradition of Scotland," In The Invention of Tradition. Hobbsbawm, E. and Ranger, T. (eds.). Cambridge. Great Britain: Cambridge University Press, 1983.

Twumasi, P. K. Medical Systems in Ghana: A Study in Medical Sociology. Accra: Ghana Publishing Corporation, 1975.

Wicker, O'Brien Kathleen. "Mame Water in African Religion and Spiritual." In African Spirituality Forms, Meanings and Expressions. Ed.Olupona, K. Jacob.. New York: Crossroad, 2000. 


\section{UNPUBLISED WORKS}

Ampom. K. Darkwa. Festivals of the Gods: Observers report on Abidjan Mame Wata, Adomi(Ewe) and Tsigaa Mame Wata, Moree(Fate-Akan). University of Ghana. Legon 1995.

Akesson. Sam K.. Traditional Beliefs and C'ustoms of the Nzema People. 1950: unpublished; found in the archives of the Western Regional House of Chiefs.

Bediako.G.M. The Relationship Between Western Missions and the Indigenous Christian Prophet of West Africa. M.A Thesis, Aberdeen: 1980.

Cudjoe. Anastasia. "Fetish Priest Exposes Pastor." People and Places, 10 August 2008, 1.

Wuaku. Albert. Tapping into I Hindu Powers: Krishna and Shiva Worship in Ghana. PhD Thesis, Toronto: University of Toronto, 2004, 200.

7aakpa. Agatha. "Women Organizations in Ghana." [website and database]. 3/01/07. available from $<$ http://www.distel.ca/womlist/countries/ghana.html $>$ accessed 10/10/08. 